\title{
The Use and Abuse of Analogy in IHL
}

\author{
KEVIN JON HELLER ${ }^{1}$
}

\section{Introduction}

It is a truism to say that conventional international humanitarian law (IHL) regulates international armed conflict (IAC) far more extensively than non-international armed conflict (NIAC). In IAC, conventional IHL - the four Geneva Conventions and the First Additional Protocol authorizes both targeting and detention and carefully circumscribes their use. In NIAC, by contrast, conventional IHL - Common Article 3 and the Second Additional Protocol - is silent on the authorization for targeting and detention and prescribes only rudimentary limits on when individuals may be targeted or detained.

Like nature, however, international law abhors a vacuum. Many of the gaps in the conventional IHL of NIAC have been slowly filled by custom. In its groundbreaking study, for example, the ICRC concluded that 138 of the 161 customary rules of IHL now apply in both IAC and NIAC - nearly $86 \% .^{2}$ A number of those customary rules simply parallel provisions in the Second Additional Protocol ${ }^{3}$ (AP II), such as the prohibition on attacking civilians ${ }^{4}$ and the obligation to protect the wounded and sick. ${ }^{5}$ But others go well beyond AP II, particularly concerning "the basic principles on the conduct of hostilities and... rules on specifically protected persons and objects and specific methods of

${ }^{1}$ My thanks to Nastasia Bach for her exceptional research assistance.

${ }^{2}$ See Emily Crawford, Unequal before the Law: The Case for the Elimination of the Distinction between International and Non-international Armed Conflicts, 20 LEIDEN JOURNAL OF InTERNATIONAL LAW 441, 457 (2007).

${ }^{3}$ Protocol Additional to the Geneva Conventions of 12 August 1949, and relating to the Protection of Victims of Non-International Armed Conflicts, Art. 1, 16 I.L.M. 1442, 1125 U.N.T.S. 609 (1977).

4 Jean-Marie Henckaerts \& Louise Doswald-Beck, Customary International Humanitarian Law: Volume 1: Rules, Rule 1 (2005).

${ }^{5}$ Id., Rules 109-11. 
warfare." ${ }^{\prime 6}$ As a result, it is now common for scholars to claim that, with the notorious exceptions of the combatant's privilege and POW status, very few critical differences remain between IAC and NIAC concerning the applicable rules of IHL. ${ }^{7}$

From a positivist perspective, of course, the gradual harmonization of IAC and NIAC through convention and custom is unproblematic. Both are formal sources of international law. ${ }^{8}$ Since $9 / 11$, however, the United States has consistently taken the position that certain IAC-based rules of IHL can be applied in NIAC via a third method: analogy. The U.S. has argued, for example, that it can target members of any organized armed group that would qualify as a "co-belligerent" of al-Qaeda under IAC rules. ${ }^{9}$ Similarly, by analogizing to the "persons accompanying" provision of the Third Geneva Convention ${ }^{10}$ (GC III), the U.S. has argued that it can detain individuals who are not members of al-Qaeda but substantially support it. ${ }^{11}$

In assessing the legitimacy of such analogies, it is tempting to focus on whether it makes sense to apply a particular IAC rule in NIAC. ${ }^{12}$ Is the Haqqani Network's relationship with al-Qaeda really equivalent to Italy's relationship with Nazi Germany? Are individuals who regularly cook for members of al-Qaeda really like supply contractors working with the U.S. Armed Forces? Emphasizing the substantive "fit" between IAC and NIAC, however, simply obscures a more fundamental question: Where does the U.S.'s authority to analogize between IAC and NIAC come from?

That is a critical question, for two reasons. First, targeting and detention each potentially violate the human rights of the individuals they affect. As the International Law Commission (ILC) has noted, it is not enough for targeting or detention to qualify as a legitimate act of

${ }^{6}$ Jean-Marie Henckaerts, Study on Customary International Humanitarian Law, 87 InT'L Rev. Red Cross 175, 189 (2005).

7 See Crawford, supra note 2, at 462-65.

${ }^{8}$ See Statute of the International Court of Justice, art. 38, 59 Stat. 1055, TS No. 993 at 25, 3 Bevans 1199.

9 See, e.g., Respondents' Memorandum Regarding the Government's Detention Authority Relative to Detainees Held at Guantanamo Bay at 7, Hamlily v. Obama, 616 F. Supp. 2d 63 (D.D.C. March 13, 2009) (No. 05-763), ECF No. 175.

${ }^{10}$ Geneva Convention (III) Relative to the Treatment of Prisoners of War, art. 4(A)(1) and (2), August 12, 1949, 6 U.S.T. 3316, 75 U.N.T.S. 135

11 See, e.g., Department of Defense Directive Number 2310.01E (August 19, 2014), Appendix, at 14.

12 See, e.g., Duncan B. Hollis, Re-Thinking the Boundaries of Law in Cyberspace: A Duty to Hack?, Temple University Research Paper No. 2014-16, at 16 (May 27, 2014) (noting that "[a] nalogical reasoning requires that the context from which the analogy originates shares sufficiently relevant similarities (and no relevant dissimilarities) with the targeted context"). 
self-defense under Art. 51 of the U.N. Charter; that targeting or detention must also be consistent with either IHL or international human rights law (IHRL), depending on which legal regime applies. ${ }^{13}$ By expanding its ability to target and detain, therefore, the U.S.'s use of analogy increases the number of acts that it must justify under IHL or IHRL.

Second, because all of the targeting and detention activities that occur in the NIAC between the U.S. and al-Qaeda take place extraterritorially, each U.S. use of force and each capture operation potentially violates the sovereignty of the state on whose territory it takes place. The U.S.'s analogies between IAC and NIAC greatly expand its ability to target and detain extraterritorially; its use of analogy thus significantly increases the number of acts that it must defend as legitimate self-defense.

Put more simply, by relying on analogized rules of IHL to justify expanded targeting and detention of al-Qaeda, the U.S. potentially runs afoul of a number of prohibitive rules of international law: the principle of non-intervention; the prohibition on the use of force; and IHRL prohibitions on the arbitrary deprivation of life and liberty. What, then, is the legal basis for those analogies?

This chapter's answer is straightforward: nothing. There is no basis in international law for taking rules of IHL that apply as a matter of convention and custom only in IAC and applying them in NIAC by analogy. The U.S. is thus systematically violating international law by relying on those analogized rules to target and detain extraterritorially.

The chapter itself is divided into two sections. Section I traces the rise of IHRL and the evolution of what has been called "transnational armed conflict" ${ }^{14}$ in order to explain why there must always be a conventional or customary basis for extraterritorial targeting and detention. Section II then explains why the absence of the required conventional or customary basis dooms each of the IAC-based rules of IHL that the U.S. has applied in NIAC by analogy.

\section{The Necessity of Convention or Custom}

Given the considerable practical impact analogized rules of IHL have had on the U.S.'s targeting and detention practices, we would expect the U.S.

${ }^{13}$ International Law Commission, Draft Articles on Responsibility of States for Internationally Wrongful Acts, with Commentaries, at 74, A/56/10 (2001).

${ }^{14}$ See generally Geoffrey Corn \& Eric Talbot Jensen, Transnational Armed Conflict: A "Principled" Approach to the Regulation of Counter-Terror Combat Operations, 42 IsR. L. Rev. 46-79 (2009). 
government (USG) to have provided a robust defense of the legality of analogy. After all, from a positivist standpoint, it is anything but selfevident that states are free to analogize at will between IAC and NIAC. The analogized rules are not applicable in NIAC via conventional law. They cannot be viewed as general principles of law. And although some scholars talk about analogizing IAC rules of IHL to NIAC through customary international law, ${ }^{15}$ that is not the argument the USG is making ${ }^{16}$ - it has never claimed that the rules it applies by analogy have achieved customary status.

In fact, the USG has never made any attempt whatsoever to explain why international law permits it to analogize between IAC and NIAC. With regard to co-belligerency, for example, Jeh Johnson has merely stated that the U.S. has "publicly defined an 'associate force' as [being]... a co-belligerent with al Qaeda in hostilities against the United States or its coalition partners." ${ }^{17}$ Similarly, with regard to detention, the Department of Justice has simply claimed that the U.S. has the authority to detain anyone "whose relationship to al-Qaida or the Taliban would, in appropriately analogous circumstances in a traditional international armed conflict, render them detainable." 18 The USG has not even been able to articulate a rationale for analogy in response to direct questions from the judiciary; an exasperated Judge Bates noted during the Hamlily litigation that "[a]fter repeated attempts by the Court to elicit a more definitive justification for the 'substantial support' concept in the law of war, it became clear that the government has none."19

Fortunately for the USG, other judges have proven far more credulous. The DC Circuit quickly rejected Judge Bates's conclusion that

15 See, e.g., Noëlle Quénivet, The Moscow Hostage Crisis in the Light of the Armed Conflict in Chechnya, 4 Y.B. Int'L Humanitarian L. 348, 361-62 (2001) (noting that "a way of arguing that analogy can be made is that 'there exists, at present, a corpus of customary international law applicable to all armed conflicts irrespective of their characterisation as international or non-international armed conflicts"') (citation omitted).

16 Silja Voneky, Analogy in International Law, in Max Planck Encyclopedia of InterNATIONAL LAW, 9, available at http://opil.ouplaw.com/home/EPIL (“[O]ne can and must differentiate between reasoning by analogy and the evidence of a rule of customary international law, even if there may be cases of doubt which are hard to decide.").

17 Jeh C. Johnson, The Conflict Against Al Qaeda and its Affiliates: How Will It End?, Speech at the Oxford Union, Oxford University (November 30, 2012), available at www.lawfareblog.com/2012/11/jeh-johnson-speech-at-the-oxford-union/\#_ftn11.

${ }^{18}$ Respondents' Memorandum, supra note 9, at 1.

19 Memorandum Opinion, at 18, Hamlily v. Obama, Civil Action No. 05-0763 (JDB) (D.D.C. 2009). 
"substantial support" did not justify detention in NIAC, and no other court District or Court of Appeals - has ever rejected an attempt by the USG to apply an IAC rule to NIAC by analogy. ${ }^{20}$ Like the USG itself, however, those courts have uniformly failed to explain why international law permits analogizing between IAC and NIAC in the absence of a customary basis for doing so. In Hamlily, for example, the same Judge Bates who showed such admirable skepticism toward the USG's "substantial support" analogy had no problem concluding that co-belligerency could be applied in NIAC. Why did he reach that conclusion, despite acknowledging that "[1]ike many other elements of the law of war, co-belligerency is a concept that has developed almost exclusively in the context of international armed conflicts"? Because - and this was the totality of his argument, itself relegated to a footnote - "there is no reason why this principle is not equally applicable to non-state actors involved in noninternational conflicts." ${ }^{21}$

American scholars have also generally failed to articulate a coherent rationale for analogizing between IAC and NIAC. Bradley and Goldsmith, for example, simply claim that the U.S. can target al-Qaeda's co-belligerents because "the laws of war at a minimum would deem 'neutrals' that systematically violate the laws of neutrality by supporting or assisting other terrorist organizations to be lawful military targets."22 In a similar vein, Lederman and Vladeck have suggested that "perhaps substantial supporters of enemy forces who are apprehended while accompanying such forces can be detained on roughly the same terms as the forces themselves, just as they can be in an international conflict. Cf. Third Geneva Convention, art. 4(4)." ${ }^{23}$ Those scholars do not explain why international law permits the analogy they endorse; they focus solely on the supposed substantive desirability of applying a particular IAC-based IHL rule to NIAC.

There is, however, one notable exception to scholarly silence on the legal basis of analogy: Ryan Goodman. Goodman defends the U.S.'s right to analogize between IAC and NIAC as follows:

20 As discussed in more detail later, the D.C. Circuit rejected applying co-belligerency to NIAC by analogy in Al-Bihani v. Obama, 590 F.3d 866, 873 (D.C. Cir. 2010). But it did so in order to reject a habeas petition filed by a Guantánamo detainee; the USG did argue analogy in that case.

${ }^{21}$ Hamlily Memorandum Opinion, supra note 19, at 16 n 16.

22 Curtis A. Bradley \& Jack Goldsmith, Congressional Authorization in the War on Terror, 118 Harv. L. Rev. 2048, 2113 (2005).

23 Marty Lederman \& Steve Vladeck, The NDAA: The Good, the Bad, and the Laws of WarPart I, Opinio Juris (December 31, 2011), available at http://opiniojuris.org/2011/12/31/ the-ndaa-the-good-the-bad-and-the-laws-of-war-part-i/ (citation in the original). 
IHL is uniformly less restrictive in internal armed conflicts than in international armed conflicts. Accordingly, if states have authority to engage in particular practices in an international armed conflict (e.g., targeting direct participants in hostilities), they a fortiori possess the authority to undertake those practices in noninternational conflict. Simply put, whatever is permitted in international armed conflict is permitted in noninternational armed conflict. Hence, if IHL permits states to detain civilians in the former domain, IHL surely permits states to pursue those actions in the latter domain. ${ }^{24}$

Goodman's defense of analogy appears to be based squarely on the Permanent Court of International Justice's seminal judgment in the Lotus case - its second principle in particular:

It does not ... follow that international law prohibits a State from exercising jurisdiction in its own territory, in respect of any case which relates to acts which have taken place abroad, and in which it cannot rely on some permissive rule of international law. Such a view would only be tenable if international law contained a general prohibition to States to extend the application of their laws and the jurisdiction of their courts to persons, property and acts outside their territory, and if, as an exception to this general prohibition, it allowed States to do so in certain specific cases. But this is certainly not the case under international law as it stands at present. Far from laying down a general prohibition to the effect that States may not extend the application of their laws and the jurisdiction of their courts to persons, property and acts outside their territory, it leaves them in this respect a wide measure of discretion, which is only limited in certain cases by prohibitive rules; as regards other cases, every State remains free to adopt the principles which it regards as best and most suitable. This discretion left to States by international law explains the great variety of rules which they have been able to adopt without objections or complaints on the part of other States.

In these circumstances all that can be required of a State is that it should not overstep the limits which international law places upon its jurisdiction; within these limits, its title to exercise jurisdiction rests in its sovereignty. ${ }^{25}$

Goodman's argument, in other words, seems to be this: (1) the ability of states to target and detain in armed conflict is limited only by prohibitive rules of IHL; (2) because there are fewer prohibitive IHL rules concerning targeting and detention in NIAC than in IAC, any targeting or detention

24 Ryan Goodman, The Detention of Civilians in Armed Conflict, 48 Am. J. InT'L L. 48, 50 (2009).

25 Lotus, 1927 P.C.I.J. (ser. A) No. 10, at 19. 
that is not prohibited in IAC cannot be prohibited in NIAC; (3) states are thus free to apply IAC-based targeting and detention rules to NIAC, because by definition such analogized rules cannot violate a prohibitive rule of IHL.

The key here is that Goodman is arguing - if only implicitly - that states are free to analogize between IAC and NIAC as a matter of domestic law, not international law. ${ }^{26} \mathrm{He}$ is not claiming that international law itself permits states to apply IAC-based rules to NIAC by analogy; his point is that states are free to adopt whatever targeting and detention principles they want in their domestic law unless something in international law prohibits them from doing so. That is why he can also insist that the "same logic ... does not apply to proscriptive rules. If IHL forbids states from engaging in particular actions in international armed conflicts, it does not necessarily follow that the same prohibition applies in a noninternational conflict." ${ }^{27}$ In terms of the second Lotus principle, the distinction between permissive and prohibitive rules makes sense: Although there is no need to demonstrate that a particular permissive rule exists in NIAC as well as in IAC, because states are free to organize their domestic law of targeting and detention however they want as long as they do not violate a prohibitive rule, there is a need to show that a particular prohibitive rule of targeting or detention applies in NIAC as well as in IAC, because - to quote another part of the Lotus judgment - "[r]estrictions upon the independence of States cannot ... be presumed." 28

This is a coherent defense of analogy - but one that is ultimately unpersuasive. Although Goodman's Lotus-like argument would have made sense prior to World War II, the rise of universal human rights and the evolution of transnational NIAC have rendered that argument obsolete. There are now at least four different prohibitive rules that limit the freedom of states to apply IAC-based targeting and detention rules to NIAC solely by analogy - namely, the principle of non-intervention, the prohibition on the use of force, and IHRL's rights to life and liberty.

Cf. Ashley Deeks, Domestic Humanitarian Law: Developing the Law of War in Domestic Courts, University of Virginia School of Law Public Law and Legal Theory Research Paper Series 2013-39, at 18 (October 2013) (distinguishing between international humanitarian law and domestic humanitarian law, and including in the latter category situations where "courts must first interpret traditional IHL principles and then apply those principles analogically to a new conflict").

27 Goodman, Detention of Civilians, supra note 24, at 50.

${ }^{28}$ Lotus, supra note 25, at 18. 


\section{A. The Absence of International Law}

Until the late 1940s, international law had almost nothing to say about how a state waged what we now call a non-international armed conflict. Because such conflicts were generally fought on the state's own territory, the principle of non-intervention and the prohibition on the use of force the latter still in its infancy anyway - did not apply. International human rights law did not yet exist. And prior to the adoption of the Geneva Conventions in 1949, IHL regulated only international armed conflicts wars between two or more states. ${ }^{29}$ The one exception was the rare civil war in which the insurgents were so organized and hostilities so intense that third states had both "the right and the duty to grant recognition of belligerency," ${ }^{30}$ which required them to treat the warring parties as if they were engaged in a traditional international armed conflict. ${ }^{31}$

In this early phase of NIAC's evolution, the second Lotus principle did indeed effectively grant a state unfettered discretion to wage war against an insurgent group. There were simply no prohibitive rules of international law that limited the kind of targeting and detention rules the state could adopt as a matter of what Deeks aptly calls "domestic humanitarian law." Indeed, the right of a state to determine how it wanted to combat an insurgency was itself a prohibitive rule of international law, one that prevented other states from claiming the right to interfere in the internal conflict. As Kretzmer notes, "[a]ny outside interference was regarded as incompatible with the principle of sovereignty, the linchpin of international law in the post-Westphalian era." ${ }^{32}$

At this point in time, then, IHL was the state's enemy, not its friend. Given that the jus ad bellum did not apply to internal NIACs and IHRL did not yet exist, IHL provided the only conceivable limits on a state's

29 David Kretzmer, Rethinking the Application of IHL in Non-International Armed Conflicts, 42 Isr. L. Rev. 8, 13 (2012); Sandesh Sivakumaran, The Law of NonInternational ARMed Conflict 222 (2012).

302 Lassa Oppenheim, International Law: A Treatise $\$ 76$, at 197 (Hersch Lauterpacht ed., 6th ed. 1940).

31 Yair M. Lootsteen, The Concept of Belligerency in International Law, 166 MiL L. Rev. 109, 114 (2000) ("While not conferring statehood, proper recognition of belligerency grants the rebels substantive protections under the laws of war.").

${ }^{32}$ Kretzmer, Rethinking, supra note 29, at 13; see also John Cerone, Jurisdiction and Power: The Intersection of Human Rights Law \& the Law of Non-International Armed Conflict in an Extraterritorial Context, 40 IsR. L. Rev. 396, 402 (2007) (noting that because conflicts "other than between states" were "traditionally not the concern of international law ... [t]he principle of non-intervention generally prevented international regulation of such conflicts"). 
freedom to do whatever it wanted to quell an insurgency. States thus went to great lengths to prevent third states from recognizing insurgent groups as belligerents, ${ }^{33}$ because once a state was involved in a recognized belligerency, it had to extend belligerent rights to the insurgents most notably, combatant's privilege and POW status - or it would lose its own belligerent rights in the eyes of third states. ${ }^{34}$ And, of course, states scrupulously resisted applying any of the major IHL conventions of the time, such as the 1907 Hague Convention IV and the 1929 Geneva Convention on the Wounded and Sick in Armies in the Field, to civil wars. ${ }^{35}$

\section{B. The Rise of IHRL}

After World War II, the number of prohibitive rules of international law multiplied exponentially. ${ }^{36}$ To begin with, conventional IHL began to regulate NIAC: Common Article 3 of the 1949 Geneva Conventions protects "persons taking no active part in the hostilities" from mistreatment in any "armed conflict not of an international character occurring in the territory of one of the High Contracting Parties,"37 while the Second Additional Protocol of 1977 regulates both detention and targeting in armed conflicts that "take place in the territory of a High Contracting Party between its armed forces and dissident armed forces or other organized armed groups which, under responsible command, exercise such control over a part of its territory."38 Those conventions, of course, do not regulate NIAC anywhere near as comprehensively as the Geneva Conventions and First Additional Protocol regulate IAC. But customary international law has closed the gaps between the two considerably: as noted earlier, the ICRC takes the position that only 23 of 161 customary rules of IHL now apply solely in IAC. ${ }^{39}$

33 See Lootsteen, supra note 31, at 114 (noting that Britain's recognition of the Civil War as a belligerency was "much to the chagrin" of Lincoln).

34 See Hersch Lauterpacht, Recognition in International Law 232 (1947) ("[I]f the lawful government were to claim belligerent rights whilst denying them to the insurgents, such illogical and one-sided conduct would invalidate its continued recognition as a belligerent.").

35 Sivakumaran, supra note 29, at $222 . \quad 36$ See generally Cerone, supra note 32.

37 See, e.g., Geneva Convention Relative to the Protection of Civilian Persons in Time of War, Art. 3, August 12, 1949, 6 U.S.T. 3516, 75 U.N.T.S. 287.

38 AP II, supra note 3, Art. 1(1). ${ }^{39}$ Crawford, supra note 2, at 457. 
The post-war expansion of conventional and customary IHL into NIAC was mirrored by the evolution of IHRL. As Rona says, "World War II gave us the Age of Rights." "The watershed moment was the U.N. General Assembly's adoption of the Universal Declaration of Human Rights (UDHR) in 1948, because its affirmation that "[e]veryone has the right to life, liberty and security of person,"41 regardless of "the political, jurisdictional or international status of the country or territory to which a person belongs," ${ }^{2}$ meant that "the relationship between a State and its citizens and residents was no longer regarded as being a matter in the sole prerogative of each State." ${ }^{33}$ The UDHR was merely hortatory, but its adoption led to the rapid proliferation of international and regional human-rights conventions whose prohibitive rules were binding on the states that ratified them, such as the European Convention on Human Rights (1953), ${ }^{44}$ the International Covenant on Civil and Political Rights (1966), ${ }^{45}$ the American Convention on Human Rights (1969), ${ }^{46}$ and the Convention Against Torture and Other Cruel, Inhuman or Degrading Treatment or Punishment (1984). ${ }^{47}$ Those conventions not only include provisions that govern the use of lethal force and detention, there is also - at least now, following the ICJ's decision in the Nuclear Weapons case $^{48}$ - no question that they continue to apply during armed conflict. ${ }^{49}$

40 Gabor Rona, A Bull in a China Shop: The "War on Terror" and International Law in the United States, 39 CaL. West. J. InT'L L. 101 (2008).

${ }^{41}$ Universal Declaration of Human Rights, Art. 3, G.A. Res. 217 (III), U.N. Doc. A/RES/217 (III) (December 10, 1948).

${ }^{42}$ Id., art. $2 .{ }^{43}$ Kretzmer, Rethinking, supra note 29, at 8-9.

44 Convention for the Protection of Human Rights and Fundamental Freedoms, 213 U.N.T.S. 222 (1953).

45 ICCPR, G.A. Res. 2200A (XXI), at 52, U.N. GAOR, 21st Sess., Supp. No. 16, U.N. Doc. A/ 6316 (December 16, 1966).

46 O.A.S. Treaty Series No. 36, 1144 U.N.T.S. 123.

47 Convention Against Torture and Other Cruel, Inhuman or Degrading Treatment or Punishment, December 10, 1984, 1465 U.N.T.S. 85 (entered into force 1987).

${ }^{48}$ Legality of the Threat or Use of Nuclear Weapons, Advisory Opinion, 1996 I.C.J. 226 (July 8), 25.

49 See, e.g., Noam Lubell, Challenges of Applying Human Rights Law to Armed Conflict, 87 InT'L Rev. Red Cross 737, 738 (2005) ("The focus of the arguments is now shifting from the question of if human rights law applies during armed conflict to that of how it applies, and to the practical problems encountered in its application."); Kretzmer, Rethinking, supra note 29, at 17 (noting that it is "quite clear that during an internal armed conflict in a State's territory that State remains bound by its human rights obligations toward those in its territory, and subject to its jurisdiction"); Louise Doswald-Beck, The Right to Life in Armed Conflict: Does International Humanitarian Law Provide All the Answers?, 88 INT'L 
The rise of the "Age of Rights" has led states to rethink their traditional aversion to regulating NIAC through IHL. Prior to World War II, states wanted to keep IHL out of NIACs fought on their territory, because the absence of IHL meant that targeting and detention were regulated solely by domestic law. Now, however, the choice is not between no international regulation and regulation by IHL, but between regulation by IHL and regulation by IHRL. And that is no contest: as discussed in more detail in Section II, the prohibitive rules of IHRL impose far greater substantive limits on targeting and detention than the prohibitive rules of IHL. As a result, states now want to ensure that IHL applies in NIAC as broadly as possible - in order to keep IHRL out. ${ }^{50}$

States' preference for IHL, of course, implicates the much-debated principle of lex specialis. As Sivakumaran notes, "in the majority of situations, a particular norm will exist both in international human rights law as well as in international humanitarian law. In such instances, the precise relationship between the two norms will have to be ascertained." ${ }^{\prime 1}$ Three basic versions of lex specialis exist: (1) total displacement, according to which IHL completely displaces IHRL in situations of armed conflict; (2) partial displacement, which accepts that both IHL and IHRL apply in armed conflict but insists that specific rules of IHL displace competing rules of IHRL (understood as rules whose application would lead to a different substantive result); and (3) principle of normconflict resolution, according to which specific rules of IHL do not "ipso facto override, displace or qualify conflicting norms of IHRL," but must always be taken into account when interpreting IHRL norms. ${ }^{52}$

Rev. Red Cross 881, 886 (2006) (noting that "human rights law does not make a distinction between armed conflict and peace").

50 See, e.g., Claus Kress, Some Reflections on the International Legal Framework Governing Transnational Armed Conflicts, 15 J. Conflict \& SeC. L. 245, 260 (2010) (noting that, "in light of the (perceived) threat posed by violent non-State actors, States seem to be more interested in availing themselves of the wider powers they can derive from the application of the law of non-international armed conflict (compared with international human rights law) than they are concerned by the restraining effect of the ensuing obligations"); $c f$. Kretzmer, Rethinking, supra note 29, at 39 ("While the original intention behind extension of IHL to non-international armed conflicts was to enhance the protection granted to potential victims of such conflicts, given the dramatic development of IHRL, categorization of a situation as one of armed conflict, rather than internal unrest, may serve to weaken the protection offered to potential victims rather than to strengthen it."). Sivakumaran, supra note 29 , at 89.

52 Marko Milanovic, The Lost Origins of Lex Specialis: Rethinking the Relationship Between Human Rights and International Humanitarian Law, this volume, at 24-28. 
It is no longer possible to defend the first version of lex specialis, for all the reasons that Milanovic has identified - state practice, the derogation provisions in human-rights conventions like the ECHR, the ICJ's Nuclear Weapons opinion, and so on. ${ }^{53}$ The crux of the debate is thus between the second and third versions. Most scholars seem to adopt the partialdisplacement view, ${ }^{54}$ though Milanovic has persuasively defended the norm-conflict-resolution view. ${ }^{55}$

We do not have to decide which version of lex specialis is correct, though, because both versions share a common assumption: namely, that an applicable rule of IHRL can be displaced or modified only by a competing rule of IHL. In the absence of a competing rule of IHL - or, differently put, in the presence of a gap in IHL - both versions of lex specialis agree that the rule of IHRL applies.

The key here is "competing rule of IHL." Scholars uniformly assume that the kind of IHL rule capable of displacing or modifying a competing rule of IHRL is one that is based on either convention or custom. ${ }^{56}$ They

53

54 See, e.g., Doswald-Beck, supra note 49, at 903-04 ("Specific, clear and well-established rules of IHL can be considered to be lex specialis."); Deborah Casalin, Taking Prisoners: Reviewing the International Humanitarian Law Grounds for Deprivation of Liberty by Armed Opposition Groups, 93 InT'L Rev. Red Cross 743, 745-46 (2011) (“IHRL still applies during NIACs to the extent that ... an IHRL rule has not been superseded by a more specific rule of IHL operating as lex specialis."); Marco Sassoli, The Relationship Between International Humanitarian and Human Rights Law Where It Matters: Admissible Killing and Internment of Fighters in Non-International Armed Conflicts, 90 INT'L Rev. Red Cross 599 (2008) (noting that lex specialis "seeks to establish ... a preferential order for two rules that apply to the same problem but regulate it differently").

55 See generally Milanovic, Lex Specialis, supra note 52.

${ }^{56}$ See, e.g., John F. Murphy, Will-o'-the-Wisp? The Search for Law in Non-International Armed Conflicts, 88 InT'L LAw STUd. 15, 25 (2012) (noting that IHL should ideally be extended to NIAC by convention, but accepting that "if this method of extension is a mission impossible, as the evidence convincingly demonstrates, then customary international law methodology will have to be employed"); Sean Watts, Present and Future Conceptions of the Status of Government Forces in Non-International Armed Conflict, 88 INT'L LAW STUD. 145, 151 (2012) ("[T] he material field of application of a number of important international law-of-war instruments has recently been expanded to NIAC. By their terms, these treaties formerly regulated only IAC. Previously, their extension to NIAC could only be achieved by proof of customary status-a technique fraught with ambiguity and subject to vexing caveat."); Jens Ohlin, Is Jus in Bello in Crisis? 11 J. INT'L CRim. Just. 27, 35 (2013) ("The gap-filling version of the co-application thesis is particularly relevant with regard to the rules applicable in NIACs which are codified only in Common Article 3 and APII, arguably leaving substantial gaps in which IHRL might be applied. However, if one argues that IAC norms apply by virtue of custom in NIAC, then the available space for IHRL to 'fill the gap' is substantially reduced."); 
have never suggested that an IHL rule that applies solely by analogy is the kind of lex capable of representing the lex specialis. On the contrary, Krieger has specifically stated that IHL "does not per se override human rights law in cases where humanitarian law itself is only applied by way of analogy," ${ }^{27}$ while Vöneky has made the more general point that because "an argument by analogy is valid only if and as far as a lacuna exists," the issue in question "must not be covered by any rule of international law or any general principle of law." 58

The idea that only a rule of international law is capable of displacing a competing rule of international law via lex specialis explains why the second Lotus principle does not, in fact, permit a state to apply an IACbased rule of IHL to NIAC by analogy. As we have seen, the argument for analogy depends upon the idea that states have the right to organize their domestic law as they see fit, subject only to prohibitive rules of international law - that is what the PCIJ meant in Lotus when it said that, with reference to a state's exercise of prescriptive and enforcement jurisdiction on its own territory, "[i]n these circumstances all that can be required of a State is that it should not overstep the limits which international law places upon its jurisdiction." ${ }^{59}$ It is true that in internal NIACs there may be no prohibitive rules of $I H L$ that prevent states from analogizing between IAC and NIAC. But there are prohibitive rules of IHRL that do so. ${ }^{60}$ Those rules could be displaced or modified by rules of IHL that exist as a matter of convention or custom, but they cannot be displaced or modified by permissive or less prohibitive rules of IHL that exist only as domestic law. A state that insists it can violate prohibitive

William Abresch, A Human Rights Law of Internal Armed Conflict: The European Court of Human Rights in Chechnya, 16 Eur. J. InT'L L. 741, 748 (2005) (“There is a broad consensus that Common Article 3 and Protocol II fail to effectively regulate many aspects of those conflicts, but some lawyers and advocates look to customary international law unwritten rules that states consider to be legally binding - to fill the gaps.").

57 Heike Krieger, A Conflict of Norms: The Relationship Between Humanitarian Law and Human Rights Law in the ICRC Customary Law Study, 11 J. Conflict \& SEC. L. 265, 273 (2006); see also Crawford, supra note 2, at 453, (“[P]olicy arguments alone are not enough to make a viable case for the elimination of the distinction between types of armed conflict. Support for the proposition needed to be found in other sources of international law, namely from state practice and from opinio juris.").

58 Voneky, supra note 16, at 16.59 Lotus, supra note 25, at 19.

${ }^{60}$ Interestingly, Goodman acknowledges in a footnote that his argument "relates only to IHL. The application of other legal regimes - e.g., human rights law - might complicate this account, especially insofar as those rules impose obligations on the exercise of state power domestically and not extraterritorially." Goodman, Detention of Civilians, supra note 24 , at 50 n. 9. 
rules of IHRL because it has relied on analogy to adopt contrary rules of "domestic humanitarian law" thus precisely "overstep[s] the limits which international law places upon its jurisdiction."

\section{Transnational NIAC}

Traditional NIACs were generally fought on "the territory of one of the High Contracting Parties," even if hostilities had a propensity to spill across state borders. Such NIACs still take place, but transnational armed conflicts - NIACs in which states are engaged in hostilities with organized armed groups located primarily, if not exclusively, on the territory of other states ${ }^{62}$ - have become increasingly common: Israel's NIAC with Hezbollah in Lebanon in 2006; Columbia's NIAC with FARC in Ecuador in 2008; Turkey's ongoing NIAC with the PKK in Iraq; and, of course, the U.S.'s seemingly endless NIAC with al-Qaeda in Afghanistan, Pakistan, Yemen, and Somalia. As we will see, the evolution of transnational NIAC both complicates and strengthens the case against analogy.

\section{IHL and IHRL}

The complication involves the relationship between IHL and IHRL. As long as a NIAC is being fought primarily on a state's own territory, there is no question that the hostilities are governed by both legal regimes (via lex specialis, however interpreted); IHRL's application is primarily territorial. ${ }^{63}$ But what about transnational NIACs? Are they governed solely by IHL or by both IHL and IHRL?

Answering that question, of course, requires addressing the difficult and much-debated issue of whether and to what extent IHRL applies extraterritorially. If IHRL does not apply extraterritorially, states are in an odd situation: unable to rely on analogy when fighting a NIAC on their territory (because of the limits IHRL imposes on their domestic law), but able to rely on analogy when fighting a transnational NIAC (because their domestic law would not be limited by IHRL.)

${ }^{61}$ Lotus, supra note 25, at 19; see also Hugh Handeyside, Note, The Lotus Principle in ICJ Jurisprudence: Was the Ship Ever Afloat?, 29 Mich. J. InT'L L. 71, 90 (2007) (noting that the ICJ in the Nuclear Weapons case "suggested that the only instance in which the Lotus principle would come into play would be one in which no principles or rules of international law could be said to restrict the state behavior in question").

${ }^{62}$ See, e.g., Watts, supra note 56, at $155 . \quad{ }_{63}$ Cerone, supra note 32, at 416. 
The better view, however, is that IHRL does apply extraterritorially, at least with regard to the rights at issue in targeting and detention - the right to life and the right to liberty. A complete examination of that issue is beyond the scope of this chapter, but three points are worth emphasizing. First, it seems clear that conventional IHRL applies to extraterritorial detention - a proposition that Van Schaack has described as "categorical." ${ }^{\text {"Th }}$ The Human Rights Committee has consistently taken that position, most recently in General Comment 35, which states that because "arrest and detention bring a person within a state's effective control, States parties must not arbitrarily or unlawfully arrest or detain individuals outside their territory." ${ }^{\prime 5}$ That conclusion is echoed by a long line of cases decided by the European Court of Human Rights (ECtHR), such as Issa, ${ }^{66}$ Öcalan, ${ }^{67}$ and Al-Skeini, ${ }^{68}$ as well as by the jurisprudence of the InterAmerican Court of Human Rights. ${ }^{69}$ Even high-ranking USG officials though not the USG itself - have acknowledged that the right not to be arbitrarily deprived of liberty applies extraterritorially. ${ }^{70}$

Second, there is also strong support for the idea that, at a minimum, prohibitive rules of conventional IHRL - particularly the right to life apply extraterritorially. The Human Rights Committee has consistently suggested as much, ${ }^{71}$ and according to Van Schaack "[a] longitudinal review" of the relevant jurisprudence "reveals a distinct trend toward an understanding that States' human rights obligations follow their agents and instrumentalities offshore whenever they are in a position to respect or to violate - the rights of individuals they confront abroad." ${ }^{, 2}$ Cerone has reached a similar conclusion, adding that "the structure of Article 2(1)

${ }^{64}$ Beth Van Schaack, The United States' Position on the Extraterritorial Application of Human Rights Obligations: Now is the Time for Change, 90 InT'L L. STUD. 20, 52 (2014).

${ }^{65}$ Human Rights Committee, General Comment No. 35: Article 9: Liberty and Security of the Person, CCPR/C/GC/35, 64 (October 28, 2014) (Advanced Unedited Version).

${ }^{66}$ Issa v. Turkey, 41 Eur. Ct. H.R. 567, 70 (2004).

67 Öcalan v. Turkey, 37 Eur. Ct. H.R. 10, 93 (2003).

68 Al-Skeini v. United Kingdom, App. No. 55721/07, 53 Eur. H.R. Rep. 589, 597, g 80 (2011).

69 See, e.g., Coard et al. v. United States, Case 10.951, Inter-Am. Comm'n H.R., Report No. 109/99, OEA/Ser.L/V/II.106 doc. 6 rev., 37 (1999).

${ }^{70}$ Harold H. Koh, Legal Advisor, U.S. Department of State, Memorandum Opinion on the Geographic Scope of the International Covenant on Civil and Political Rights, at 4 (October 19, 2010), available at http://justsecurity.org/wp-content/uploads/2014/03/ state-department-iccpr-memo.pdf.

${ }^{71}$ See David Kretzmer, Targeted Killing of Suspected Terrorists: Extrajudicial Executions or Legitimate Means of Defence?, 16 Eur. J. INT'L L. 171, 184 (2005).

72 Van Schaack, supra note 64 , at 32. 
of the ICCPR supports the notion that negative obligations apply vis-à-vis all individuals everywhere, whereas positive obligations may have a more limited scope."73

Finally, even if the right to life does not apply extraterritorially as a matter of conventional law, it almost certainly applies extraterritorially as a matter of custom. As Kretzmer notes, "[w]hile a state party's treaty obligations are a function of the scope of application defined in the particular treaty, some of the substantive norms in human rights treaties that have been ratified by the vast majority of states in the world, have now become peremptory norms of customary international law. The duty to respect the right to life is surely one of these norms." ${ }^{74}$ Many other scholars - of very different political persuasions - agree. ${ }^{75}$

Because IHRL's rights to life and liberty almost certainly apply extraterritorially, states are no more free to rely on analogy in transnational NIAC than they are in purely internal NIAC. In both situations, their freedom to adopt targeting and detention rules as domestic humanitarian law is limited by the prohibitive rules of IHRL.

\section{IHL, the Principle of Non-Intervention, and the Jus ad Bellum}

As long as states fought NIACs on their own territory, IHRL represented the only possible limitation on their targeting and detention practices. But once NIACs went transnational, the legal landscape changed dramatically:

Transnational armed conflict greatly strains traditional territorial or politically based claims of exclusive sovereign prerogative on the part of the government under attack. Classic, non-extraterritorial NIAC has relied greatly on traditional notions of territorial sovereignty to fend off

${ }^{73}$ Cerone, supra note 32, at 446.

${ }^{74}$ Kretzmer, Targeted Killing, supra note 71, at 184-85.

75 See, e.g., Michael N. Schmitt, Extraterritorial Lethal Targeting: Deconstructing the Logic of International Law, 52 Colum. J. Trans. L. 77, 110 (2013) ("[T]here is nevertheless a customary international human rights law right to life that applies extraterritorially."); Noam Lubell, Extraterritorial Use of Force Against Non-State Actors 235 (2010) ("Since forcible measures, such as killings and torture, are in fact a subject of customary international law, extraterritorial measures of this type can amount to a violation of international human rights obligations, regardless of treaty applicability and how it is interpreted."); Cerone, supra note 32, at 436 (noting, with respect to conventional IHRL, that "this limitation of scope may not apply with respect to those human rights norms that have evolved into customary international law. Thus, all states may be bound by these norms in their dealings with anyone anywhere"). 
international regulation. With their cross-border incursions and movements, transnational armed conflicts unmoor NIAC from many of its traditional claims to general freedom from international regulation. ${ }^{76}$

In particular, the extraterritorial targeting and detention that are regular aspects of transnational NIAC implicate the first Lotus principle, which says that states cannot exercise enforcement jurisdiction on the territory of another state unless a permissive rule of international law allows them to do so:

The first and foremost restriction imposed by international law on a State is that - failing the existence of a permissive rule to the contrary - it may not exercise its power in any form in the territory of another State. In this sense jurisdiction is certainly territorial; it cannot be exercised by a State outside its territory except by virtue of a permissive rule derived from international custom or from a convention.

Far from laying down a general prohibition to the effect that States may not extend the application of their laws and the jurisdiction of their courts to persons, property and acts outside their territory, it leaves them in this respect a wide measure of discretion, which is only limited in certain cases by prohibitive rules. ${ }^{77}$

All transnational NIACs have to confront the first Lotus principle - but its implications are particularly acute for the U.S.'s transnational NIAC with al-Qaeda, in which the USG is applying a variety of permissive IAC-based rules of IHL by analogy. At the domestic level, the U.S.'s right to use force against al-Qaeda is governed by the AUMF, which provides, in relevant part, that "the President is authorized to use all necessary and appropriate force against those nations, organizations, or persons he determines planned, authorized, committed, or aided the terrorist attacks that occurred on September 11, 2001." ${ }^{78}$ As discussed in more detail in Section II, by analogizing between IAC and NIAC, the USG has greatly expanded the number of persons against whom it is entitled to use force extraterritorially under the AUMF - it can target al-Qaeda's "associated forces" as well as Al-Qaeda itself because of the analogy to co-belligerency; it can detain individuals who "substantially support" either because of the analogy to "persons accompanying" in GC III; and so on. More importantly, the U.S. has almost certainly actually used more extraterritorial force in its transnational NIAC with al-Qaeda than it would have in the absence of

76 Watts, supra note 56, at $156 . \quad 77$ Lotus, supra note 25, at 99 45, 46.

78 Authorization for Use of Military Force, Pub. L. No. 107-40, 115 Stat. 224 (2001). 
analogy. It is reasonable to assume, for example, that the drone program in Somalia would look very different if the USG could not use co-belligerency to connect al-Shabaab to al-Qaeda.

Each time it relies on the AUMF to extraterritorially target or detain a member of "al-Qaeda and its associated forces," however, the U.S. must avoid violating the first Lotus principle. Simply put, extraterritorial targeting and detention are each potentially limited by two different prohibitive rules of international $\mathrm{law}^{79}$ : the prohibition on the use of force in Art. 2(4) of the UN Charter; and the principle of nonintervention, "the obligation of states to refrain from performing jurisdictional acts within the territory of other states except by virtue of general or special permission." 80 Any act that violates the prohibition on the use of force will violate the principle of non-intervention, ${ }^{81}$ but not all acts that violate the principle of non-intervention will violate the prohibition on the use of force - the principle of non-intervention applies to extraterritorial material acts of enforcement jurisdiction generally, while the prohibition on the use of force applies only to those extraterritorial material acts that involve the "threat or use of force." 82

It is uncontroversial that extraterritorial targeting qualifies as a "use of force" for purposes of Art. 2(4); that is the position of both the U.N. ${ }^{83}$ and most scholars. ${ }^{84}$ The U.S. has also acknowledged that the jus ad bellum applies to its targeted killings - it has always defended them by

79 The ICJ made clear in the Nicaragua case that although there is substantial overlap between the prohibition on the use of force and the principle of non-intervention, they are different prohibitive rules under customary international law. See Military and Paramilitary (Nicar. v. U.S.), 1986 I.C.J. 14 (June 27), 185.

80 Elihu Lauterpacht, I International LaW 487-88 (1970); see also Nicaragua, supra note 79, at 202 ("The principle of non-intervention involves the right of every State to conduct its affairs without outside interference.").

${ }^{81}$ Michael C. Bonafede, Note, Here, There, and Everywhere: Assessing the Proportionality Doctrine and U.S. Uses of Force in Response to Terrorism After the September 11 Attacks, 88 Cornell L. Rev. 155, 169 (2002).

${ }^{82}$ Nicaragua, supra note 79, at 202.

83 Report of the Special Rapporteur on Extrajudicial, Summary or Arbitrary Executions, Philip Alston, at 34, U.N. Doc. A/HRC/14/24/Add.6, (May 28, 2010) ("Targeted killings conducted in the territory of other States raise sovereignty concerns. Under Article 2(4) of the U.N. Charter, States are forbidden from using force in the territory of another State.").

${ }^{84}$ See Nils Melzer, Targeted Killing in International LaW 51 (2008) ("Authors generally agree that, in principle, the resort by a State to targeted killings within another State falls under the prohibition on interstate force expressed in Article 2(4) U.N. Charter"); see also Tom Ruys, The Meaning of "Force" and the Boundaries of the Jus ad Bellum: Are "Minimal" Uses of Force Excluded from UN Charter Article 2(4)?, 108 Ам J. INT'L L. 159, 209 (2014) ("[A] deliberate projection of lethal force onto the territory of 
invoking self-defense under Art. 51 of the U.N. Charter, and that right exists only in relation to acts that violate Art. 2(4) ${ }^{85}$ An unjustified act of extraterritorial targeting thus violates both the jus ad bellum and the principle of non-intervention.

There is some controversy, by contrast, over extraterritorial detention. The general view is that a capture operation on another state's territory qualifies as a use of force under Art. 2(4), ${ }^{86}$ and the U.S. has specifically invoked self-defense when asked to provide a legal justification for such operations - most recently with regard to the capture of Ahmed Abu Khattalah in Libya. ${ }^{87}$ Nevertheless, some scholars continue to insist that such operations are the kind of " $[\mathrm{m}]$ inimal or de minimis uses of force [that] fall below the threshold of the Article 2(4) prohibition." 88 The Independent International Fact-Finding Mission on the Conflict in Georgia has taken the same position. ${ }^{89}$ That dispute is inconsequential here, however, because all scholars agree that, at a minimum, extraterritorial capture and detention can violate the principle of non-intervention. ${ }^{90}$

another state - even if small-scale and even if not targeting the state itself - will normally trigger Article 2(4).").

${ }^{85}$ See, e.g., Department of Justice White Paper, Lawfulness of a Lethal Operation Directed Against a U.S. Citizen Who Is a Senior Operational Leader of Al Qa'ida or an Associated Force, at 3 (Undated), available at http://msnbcmedia.msn.com/i/msnbc/sections/news/ 020413_DOJ_White_Paper.pdf (“Any operation of the sort addressed here would be conducted in a foreign country against a senior operational leader of al-Qaida or its associated forces who poses an imminent threat of violent attack against the United States. A use of force in such circumstances would be justified as an act of national self-defence.").

${ }^{86}$ See Dan E. Stigall, Ungoverned Spaces, Transnational Crime, and the Prohibition on Extraterritorial Enforcement Jurisdiction in International Law, 3 Notre DAme J. INT'L L 1, 18 (2013) ("With regard to an extraterritorial arrest, such action is considered to be a use of force in the territory of another sovereign and is tantamount to abduction."); see also Ruys, Use of Force, supra note 84, at 197.

87 Letter from Samantha Powers to Vitaly Churkin, President of the United Nations Security Council (June 17, 2014), available at http://justsecurity.org/15436/war-powersresolution-article-51-letters-force-syria-isil-khorasan-group/ (claiming that those actions "were taken in accordance with the United States' inherent right of self-defense"); see also Abraham Sofaer, Irregular Apprehension of Criminal Suspects, 84 Aм. J. InT'L L. 725, 727 (1990) ("Arrests in foreign states without their consent have no legal justification under international law aside from self-defense.").

${ }^{88}$ Mary Ellen O'Connell, The Prohibition on the Use of Force, in Research Handbook on International Conflict and Security Law 89, 102 (Nigel White \& Christian Henderson eds., 2013).

89 See 2 Report of the Independent International Fact-Finding Mission on the Conflict in Georgia 242 n. 49 (2009).

90 See, e.g., Elihu Lauterpacht, supra note 80, at 488 (noting that the principle prohibits "the sending of agents for the purpose of apprehending within foreign territory persons 
Extraterritorial targeting and detention thus each potentially violate at least one prohibitive rule of international law: targeting potentially violates both the prohibition on the use of force and the principle of nonintervention; detention potentially violates either the prohibition on the use of force or the principle of non-intervention. That does not mean that the extraterritorial targeting and capture conducted pursuant to analogized rules of IHL is necessarily unlawful. But it does mean that the U.S. is not free to engage in such targeting and detention as it sees fit. On the contrary, the U.S. must a find a permissive rule of international law that legitimizes its analogy-based extraterritorial targeting and detention; as the PCIJ said in Lotus, "the first and foremost restriction imposed by international law on a State is that - failing the existence of a permissive rule to the contrary - it may not exercise its power in any form in the territory of another State."

Two such permissive rules, of course, immediately suggest themselves. The first is consent: extraterritorial targeting and detention do not violate either the prohibition on the use of force or the principle of nonintervention when a state is acting with the consent of the territorial state. ${ }^{91}$ Such situations are not uncommon, but they are clearly not the norm. The U.S. is thus more likely - as indicated by past practice - to invoke the second permissive rule: self-defense. Self-defense under Art. 51 of the U.N. Charter is a prototypic exception to the prohibition on the use of force, and the ICJ suggested in the Nicaragua case that selfdefense can also justify breaches of the principle of non-intervention. ${ }^{92}$

A use of force must satisfy three requirements in order to qualify as self-defense. The first two are well-known, if under-studied: necessity and proportionality. ${ }^{93}$ As Section II discusses in detail, because many acts of

accused of having committed a crime"); Simon Chesterman, The Spy Who Came in from the Cold War: Intelligence and International Law, 27 Мich. J. InT'L L. 1071, 1082 (2006) (noting that the principle "would clearly cover unauthorized entry into territory" and "unauthorized use of territory, such as Italian claims that CIA agents abducted an Egyptian cleric in Milan in February 2003"); INT'L BAR Ass'N, Report of the TASK ForCe on Extraterritorial JurisDiction 10 (2009) ("[A] state cannot investigate a crime, arrest a suspect, or enforce its judgment or judicial processes in another state's territory without the latter state's permission.").

91 See, e.g., Alston Report, supra note 83, at 35; Melzer, supra note 84, at 51.

92 Nicaragua, supra note 79, at 210; see also Sofaer, supra note 87, at 727 ("[I]nternational law ... permits extraterritorial "arrests" in situations which permit a valid claim of self-defense.").

93 See Tom Ruys, "Armed Attack" and Article 51 of the U.N. Charter 94 (2010) ("Notwithstanding the broad consensus as to their limiting role, the necessity and proportionality criteria have generated relatively little (in-depth) academic interest."). 
analogy-justified extraterritorial targeting and detention will violate the proportionality requirement, the U.S.'s application of those rules in transnational NIAC is problematic.

The third requirement of self-defense is of particular relevance to the legitimacy of applying IAC-based rules of IHL to NIAC by analogy: selfdefensive acts must comply with IHL in order to be lawful under the jus ad bellum. This requirement is generally ignored in contemporary debates about self-defense under Art. 51, but it was specifically affirmed by the ICJ in the Nuclear Weapons case:

[A] use of force that is proportionate under the law of self-defence, must, in order to be lawful, also meet the requirements of the law applicable in armed conflict which comprise in particular the principles and rules of humanitarian law. ${ }^{94}$

The ICJ's conclusion does not simply re-state the uncontroversial idea that compliance with the jus ad bellum does not free an attacker from the need to comply with IHL. What it means is that - as Christopher Greenwood has noted - an extraterritorial use of force that does not comply with IHL violates both the jus in bello and the jus ad bellum:

[T] he logical justification for holding that a state which is entitled to use force must comply with the jus in bello lies in considerations of the jus ad bellum, namely that an act which contravened the jus in bello could not be a reasonable and proportionate measure of self-defence. In that sense, the rules of the jus in bello give detailed expression to one of the principles of the jus ad bellum. ${ }^{95}$

94 Nuclear Weapons, supra note 48 , at 42.

95 Christopher Greenwood, The Relationship Between Ius ad Bellum and Ius in Bello, 9 Rev. InT'L STUd. 221, 231 (1983); see also Andreas Zimmerman, The Second Lebanon War: Jus ad Bellum, Jus in Bello and the Issue of Proportionality, 11 Max Planck Y.B. U.N. L. 99, 124 (2007) ("[A] further prerequisite relates to the fact that measures taken under Article 51 of the Charter must be also legal for purposes of jus ad bellum, i.e., must abide by applicable rules of international humanitarian law. This inter-linkage between jus ad bellum and jus in bello was unequivocally confirmed by the ICJ in its Advisory Opinion concerning the Legality of the Threat or Use of Nuclear Weapons."); Eyal Benvenisti, Rethinking the Divide Between Jus ad Bellum and Jus in Bello in Warfare Against Nonstate Actors, 34 YAle J. INT'L L. 541, 542 n. 6 (2009) (“Although the jus ad bellum assessment does not depend on jus in bello considerations, a response to aggression that harms noncombatants excessively would be regarded itself as a jus ad bellum violation."); Judith Gardam, Necessity, Proportionality, and the Use of Force by States 168-69 (2004) ("From time to time, there have been suggestions that issues such as the means and methods of warfare adopted by a State in the exercise of its right of selfdefence are purely in the province of IHL.... However, the requirements of proportionality in its jus ad bellum sense must also be met."). This is also clear from 
This requirement creates a serious problem for the use of analogy. As we have seen, rules of IHL that are applied in NIAC by analogy to IAC do not represent international law; they have no basis in convention or custom. Those rules are simply domestic law, their application ostensibly justified by NIAC's relative lack of prohibitive conventional and customary IHL rules. But the jus ad bellum (and thus presumably the principle of nonintervention) requires compliance with international humanitarian law the conventional or customary laws of war. Nothing in the Nuclear Weapons opinion or in the writings of scholars like Greenwood suggests that a use of force satisfies the jus ad bellum as long as it complies with the domestic humanitarian law of the attacking state. And indeed, that idea seems fundamentally at odds with the assumption underlying the IHLcompliance requirement: namely, that a state is only entitled to use force extraterritorially when its actions are consistent with all of the prohibitive rules of international law, from the jus ad bellum to the jus in bello.

To be fair, it might be argued - drawing on Goodman's work - that as long as an analogized rule does not violate a specific prohibitive conventional or customary rule of IHL that applies in NIAC, extraterritorial targeting or detention conducted pursuant to that rule cannot be considered "inconsistent" with IHL. Such an argument, however, seems to rely on a counterintuitive understanding of consistency. As long as an analogized rule allows for the targeting or detention of individuals who could not be targeted or detained under conventional and customary rules of IHL, such targeting and detention cannot be considered consistent with - cannot "meet the requirements of" - IHL. In other words, using analogy to expand the reach of IHL in NIAC beyond conventional or customary law is a form of inconsistency.

That said, the response does highlight an unresolved issue in the jus ad bellum. The Nuclear Weapons case focused on armed conflict; it did not address a situation in which a state uses the kind of force that triggers the jus ad bellum during peacetime. Presumably, in such situations, the jus ad bellum requires the use of force not only to be necessary and proportionate, but also to comply with the applicable rules of IHRL. Assume, for example, that an act of self-defense involving targeted killing would be

the context of paragraph 42 in the Nicaragua judgment. Paragraph 40 introduced the following paragraphs by stating that " $t$ t]he entitlement to resort to self-defence under Article 51 is subject to certain constraints. Some of these constraints are inherent in the very concept of self-defence. Other requirements are specified in Article 51." Nicaragua, supra note 79 , at 40 . 
"arbitrary" under either IHL or IHRL. If that act would violate the jus ad bellum in an armed conflict, it would surely also violate the jus ad bellum in peacetime.

\section{Specific Analogies}

From an international law perspective, in short, the U.S. practice of applying IAC-based rules of IHL to NIAC by analogy is very difficult to justify. Because those analogized rules represent domestic law, not international law, Lotus permits the U.S. to apply them only insofar as they do not run afoul of a prohibitive rule of international law. With the rise of human rights and the evolution of transnational NIAC, however, a number of prohibitive rules now potentially limit the use of analogy in the context of targeting and detention: the rules of IHRL, which apply to all NIACs, as well as the principle of non-intervention and the prohibition on the use of force, which apply in transnational armed conflict. Insofar as an analogized rule results in targeting or detention that violates one or more of those prohibitive rules, therefore, the U.S. is violating international law.

This section now turns to specific analogies between IAC and NIAC most applied by the U.S., but one defended by scholars who believe that analogy to IAC permits organized armed groups to detain individuals in NIAC. As we will see, because none of the analogies have a basis in conventional or customary international law, they all violate the prohibitive rules of IHRL, the prohibitive rules governing extraterritorial targeting and detention, or both.

\section{A. "Ongoing" Self-Defense}

In a speech at Harvard in 2011, John Brennan, then the Assistant to the President for Homeland Security, claimed that because the U.S. was engaged in an armed conflict with al-Qaeda, the USG "takes the legal position that - in accordance with international law - we have the authority to take action against al-Qa'ida and its associated forces without doing a separate self-defense analysis each time." ${ }^{\text {96 }}$ According to Brennan, in other words, the requirements of self-defense under

96 John O. Brennan, Strengthening our Security by Adhering to our Values and Laws, Speech at Harvard University (September 16, 2011), available at www.whitehouse.gov/the-press-office/ 2011/09/16/remarks-john-o-brennan-strengthening-our-security-adhering-our-values-an. 
Art. 51 of the U.N. Charter - necessity, proportionality, and compliance with IHL - applied only to the U.S.'s initial act of self-defense against alQaeda; because its response (arguably) complied with those requirements, its subsequent acts of targeting and detention against "al-Qaeda and its associated forces" were and are subject solely to IHL.

Brennan cited only "international law" for this position, which we might call "ongoing" self-defense, but it appears to be based on analogy to a particular understanding of self-defense in IAC that has been articulated by Dinstein, Ago, and Kunz. Dinstein argues that " $[t]$ here is no support in the practice of States for the notion that proportionality remains relevant - and has to be constantly assessed - throughout the hostilities in the course of war. Once war is raging, the exercise of selfdefence may bring about 'the destruction of the enemy's army', regardless

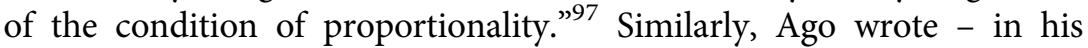
capacity as the ILC's Special Rapporteur for State Responsibility - that " $t$ ] he limits inherent in the requirement of proportionality are clearly meaningless where the armed attack and the likewise armed resistance to it lead to a state of war between two countries." ${ }^{98}$ And Kunz took the position that self-defense is not limited to repelling an armed attack, but "seems to give the state or states exercising the right of individual or collective self-defense the right to resort to a justified war, to carry this war to victory, to impose a peace treaty upon the vanquished aggressor." 99

It is easy to see why the U.S. would want to analogize this IAC-based understanding of self-defense to its NIAC with al-Qaeda: it insulates the U.S. from the claim that although it was clearly entitled to act in selfdefense in response to al-Qaeda's initial armed attack - especially an attack of the magnitude of 9/11 - its subsequent actions have exceeded the limits of proportionality. Differently put, "ongoing" self-defense permits the U.S. to completely destroy al-Qaeda and its associated forces - to "carry this war to victory" - even if a less ambitious warfighting strategy would completely neutralize the threat of armed attack posed by those groups.

Ongoing self-defense might have represented positive international law prior to World War II - the type of large-scale war that Dinstein,

97 Yoram Dinstein, War, Aggression, and Self-Defense 237 (4th ed. 2005).

98 Robert Ago, Addendum to Eighth Report on State Responsibility, [1980] II ILC Y.B. 13, 70.

99 Josef L. Kunz, Individual and Collective Self-Defense in Article 51 of the Charter of the United Nations, 41 Am. J. InT'L L. 872, 876-77 (1947). 
Ago, and Kunz were addressing. ${ }^{100}$ Post-Charter practice, however, indicates that the doctrine no longer applies even in IAC. Ruys notes, for example, that although the international community might have been prepared to accept that the U.S. acted in self-defense when it invaded the Dominican Republic in 1965 to protect its citizens, many states unequivocally condemned the U.S.'s later decision to overthrow the left-wing regime because they believed regime change was disproportionate to that goal. ${ }^{101}$ Similarly, Gardam points out that even if states accepted the idea that the U.S. invasion of Panama in 1989 was a legitimate act of self-defense, they did not believe that protecting American nationals justified removing General Noriega from power. ${ }^{102}$ Indeed, the idea of ongoing self-defense is generally inconsistent with state practice that insists self-defense must be temporally limited - a proportionality factor that by definition must be assessed in media res. ${ }^{103}$

It is also worth noting that Dinstein, Ago, and Kunz are very much in the minority concerning ongoing self-defense. Most scholars believe that each and every use of force during an armed conflict is subject to the same self-defense requirements as a state's initial response to an armed attack. ${ }^{104}$ Greenwood's position is typical:

This requirement of proportionality ... means that it is not enough for a state to show that its initial recourse to force was a justifiable act of self-defence and that its subsequent acts have complied with the jus in bello. It must also show that all its measures involving the use of force,

100 Dinstein specifically cites World War II as an example, Dinstein, supra note 97, at 240, and Kunz was writing in 1947.

101 See RuYs, supra note 93, at 117. 102 Gardam, supra note 95, at 166-67.

103 See RuYs, supra note 93, at 119-20.

104 See also Id. at 123-24 ("There exists no neat separation between the two, in the sense that necessity would determine when defensive action would be permissible, whereas proportionality would be the standard to evaluate what could be done in self-defence: to the contrary, both standards must constantly be kept under review and overlap to a certain degree."); Robert D. Sloane, The Cost of Conflation: Preserving the Dualism of Jus ad Bellum and Jus in Bello in the Contemporary Law of War, 34 YALE J. INT'L L. 47, 68 (2009) ("Even more generally, the jus ad bellum now applies not only to the initial decision to resort to force but also to all conduct 'involving the use of force which occurs during the course of hostilities'. That conduct must be necessary and proportionate to the casus belli.") (citation omitted); GardaM, supra note 95, at 156 ("Proportionality, moreover, remains relevant throughout a conflict. A State cannot assess proportionality at the time of making the decision as to the appropriate response to an armed attack and then dispense with it."); David Kretzmer, The Inherent Right to Self-Defence and Proportionality in Jus Ad Bellum, 24 Eur. J. INT'L L. 235, 267-68 (2013) ("War aims may have to be redefined and consideration given to the necessity of using further force as well as caused by pursuing those aims. Hence, examining the proportionality of the force may become an ongoing process."). 
throughout the conflict, are reasonable, proportionate acts of self-defence. Once its response ceases to be reasonably proportionate then it is itself guilty of a violation of the jus ad bellum. The fact that the modern jus ad bellum thus applies during a conflict has important legal consequences. It means that an attack carried out in the middle of a conflict upon what is, in terms of the jus in bello, a legitimate military target by methods which are not forbidden by the jus in bello will nevertheless be a violation of international law if it cannot be justified by reference to the principle of self-defence. ${ }^{105}$

It is unclear whether Ago and Kunz would disagree in the context of NIAC; both wrote long before NIAC went transnational. (Kunz wrote in 1947; Ago in 1980.) Dinstein, however, would almost certainly be skeptical of analogizing between IAC and NIAC in the context of ongoing self-defense: he specifically distinguishes between a "war of self-defense" and self-defense that responds to an "isolated armed attack" of the kind that normally triggers a transnational NIAC, suggesting that proportionality remains relevant during self-defense of the latter type. ${ }^{106}$

More importantly, though, state practice simply does not support the U.S. claim that ongoing self-defense applies in NIAC, as the international response to the 2006 NIAC in Lebanon fought by Israel and Hezbollah demonstrates. Initially, many states - ranging from Denmark to Japan to Tanzania - supported Israel's right to use force against Hezbollah in self-defense. ${ }^{107}$ As the NIAC dragged on and Lebanese civilian casualties continued to mount, though, more and more states claimed that Israel's actions had become disproportionate - including states such as France and Argentina, which had supported Israel at the outbreak of the conflict. $^{108}$

In short, and pace Brennan's Harvard speech, state practice in both IAC and NIAC indicate that, as most scholars believe, ongoing self-defense has no relevance in any kind of armed conflict.

105 Greenwood, Relationship, supra note 95, at 223. It is worth noting Greenwood acknowledges that, in practice, the continuing applicability of the jus ad bellum would not mean much in the context of an existential conflict such as World War II. Id.; see also RuYs, supra note 93, at 117 ("In extreme cases (for instance, if one State were to commence an all-out war against another), this would even warrant the defending State pursuing a total military defeat of the attacking State or the removal of its regime.").

Dinstein, supra note 97 , at 238 .

107 Christine Gray, The Bush Doctrine Revisited: The 2006 National Security Strategy of the USA, 5 Chinese J. InT'L L. 555, 573 (2006).

108 Id. at 575 . 


\section{B. Declarations of War}

This U.S. analogy is its most ambitious: relying on "declarations of war" by organized armed groups to establish the existence of a NIAC. Specifically, the U.S. has consistently argued in the al-Nashiri and al-Qosi cases that its NIAC with al-Qaeda began when Osama bin Laden declared war on the U.S. in 1996. Here, for example, is how the USG replied to the alQosi's argument that no NIAC existed because the U.S. did not consider itself at war with al-Qaeda prior to 9/11:

While the events of September 11, 2001, no doubt constitute an act of war, that day was not the start of the armed conflict with al Qaeda. Rather, the United States has been engaged in a [non]international armed conflict with al Qaeda since at least the mid-1990s. Indeed, al Qaeda declared war on the United States in 1996. Importantly, a state of armed conflict exists even if one party does not recognize a state of war. Geneva Convention I, Article II (1949). Here, al Qaeda has organized, planned, and carried out attacks against United States as well as its citizens, diplomats, and military personnel around the world, consistent with its 1996 declaration of war. ${ }^{109}$

The USG's reliance on bin Laden's declaration of war in al-Qosi is clearly based on analogy to IAC, as the citation to the First Geneva Convention (GC I) indicates. Similarly, the USG has defended its position by noting that " $\mathrm{t}$ ] he Law of War applies to all cases of declared war or any other armed conflicts that arise between the U.S. and other nations, even if the state of war is not recognized by one of them"110 - an explicit reference to IAC. ${ }^{111}$

It is not surprising that the U.S. wants to analogize between IAC and NIAC with regard to the beginning of armed conflict. Relying on bin Laden's declaration of war has three distinct advantages. First, by temporally expanding the NIAC between the U.S. and al-Qaeda, it ensures that more targeting and detention are governed by the rules of IHL instead of by IHRL's much more restrictive rules. The U.S. may not

U.S. v. Al-Qosi, Government Response to Defense Motion to Dismiss the Charges for Lack of Subject Matter Jurisdiction to the Extent They Related to the Period Prior to 11 September 2001, D-013, at 1 (November 7, 2008). At least one American scholar has taken the same position. See Karl S. Chang, Enemy Status and Military Detention in the War Against Al-Qaeda, 47 Tex. InT'L L. J. 1, 57 (2011).

110 International and Operational Law Department The Judge Advocate General's Legal Center and School, The Operational Law Handbook 15 (2007).

111 Al-Qosi, Government Response, supra note 109, at 1. 
accept that IHRL applies extraterritorially, but it is keenly aware that its allies, particularly in Europe, do not share its position. ${ }^{112}$ It thus has a political interest, if not a legal one (according to its understanding of IHRL), in bringing as many acts of targeting and detention as possible within the rubric of IHL. Second, and relatedly, because IHL's rules concerning targeting and detention are far less restrictive than IHRL's rules, expanding the temporal limits of the U.S./al-Qaeda NIAC makes it easier for the U.S. to satisfy the final requirement of the jus ad bellum discussed earlier: demonstrating that its extraterritorial uses of force comply with the applicable rules of IHL or IHRL. Third, the U.S. must expand the temporal limits of its NIAC with al-Qaeda in order to prosecute al-Qosi and al-Nashiri in military commissions, because those commissions only have jurisdiction over acts committed during armed conflict. ${ }^{113}$

There is, however, no conventional or customary basis for determining the existence of NIAC by reference to "declarations of war" by an organized armed group. ${ }^{114}$ Neither CA3 nor AP II defines NIAC, and there is widespread agreement - among scholars ${ }^{115}$ and by the International Law Association ${ }^{116}$ - that the ICTY's definition of NIAC in Tadic $^{117}$ reflects customary international law. Under Tadić, declarations of war are irrelevant; whether a NIAC exists is determined solely by reference to the organization of the parties and the intensity of the hostilities. ${ }^{118}$ That is a purely objective test - a party's intent, whether

112 Koh, Memorandum Opinion, supra note 70, at 2-3.

113 Hamdan v. Rumsfeld, 548 U.S. 557, 639 (2006).

114 For that matter, there is no longer a basis in convention or custom for determining the existence of $I A C$ by reference to declarations of war. See International Law Association, Final Report on the Meaning of Armed Conflict in International Law, at 33 (2010), available at www.ila-hq.org/download.cfm/docid/2176DC63-D268-4133-8989A664754F9F87 ("The earlier practice of states creating a de jure state of war by a declaration is no longer recognized in international law.").

115 Sivakumaran, supra note 29, at 155 (noting that the Tadić definition "has since been adopted by a variety of influential actors and is widely recognized as authoritative. It defines the notion of an armed conflict for the purposes of Article 3 common to the four Geneva Conventions of 1949 as well as the notion of a non-international armed conflict in customary international law").

116 Final Report on the Meaning of Armed Conflict, supra note 114, at 3. The ILA reached that conclusion based on an exhaustive multi-year study of the armed conflicts that took place between 1945 and 2010. Id. at 2.

117 Prosecutor v. Tadić, Case No. IT-94-1-I, Decision on Defence Motion for Interlocutory Appeal on Jurisdiction, 70 (October 2, 1995).

118 Final Report on the Meaning of Armed Conflict, supra note 114, at 28-29. 
to affirm or deny the existence of NIAC, has no bearing on whether the requisite organization and intensity of hostilities exist. ${ }^{19}$

\section{Targeting}

The "cardinal rule" of targeting in IHL is the principle of distinction. ${ }^{120}$ That principle, which applies in both IAC and NIAC, ${ }^{121}$ is articulated most clearly in Art. 51(2) of AP I: "[t]he civilian population as such, as well as individual civilians, shall not be the object of attack." ${ }^{\prime 22}$ In IAC, anyone who is neither a member of a party's armed forces nor a participant in a levée en masse is a civilian. ${ }^{123}$ In NIAC, a civilian is anyone who is neither a member of the State's armed forces nor a member of an organized armed group. ${ }^{124}$ As long as they are not hors de combat, members of the armed forces and members of organized armed groups can be targeted at any time ${ }^{125}$ - even when they are not fighting. ${ }^{126}$ Civilians, by contrast, are targetable only if they directly participate in hostilities (DPH), and they can only be targeted "for such time as" they are participating. ${ }^{127}$ It is always permissible to use lethal

$119 I d$. at 33. It is worth noting that scholars recognized that declarations of war by organized armed groups were irrelevant to the existence of armed conflict long before the ICTY decided Tadić. In 1932, Quincy Wright noted that insurgents, "not being recognized states, have no power to convert a state of peace into a state of war, so their declaration or recognition of war would have no legal effect." Quincy Wright, When Does War Exist?, 26 Am. J. InT'L L. 362, 366 (1932). Similarly, Lothar Kotzsch noted in 1956 that "any declaration of war on the part of the seditious party is bare of any relevance in international law," because "[m]aterial war" is determined "by facts alone." Lothar Kotzsch, The Concept of War in Contemporary History and InterNATIONAL LAW 231 (1956). In other words, even when declarations of war had legal effect, they mattered only insofar as they were made by states.

120 Geoffrey Corn, Targeting, Command Judgment, and a Proposed Quantum of Information Component, 77 Brooklyn L. Rev. 437, 441 (2011-2012).

121 Customary IHL Study, supra note 4 , at 3.

122 Protocol Additional to the Geneva Conventions of 12 August 1949, and Relating to the Protection of Victims of International Armed Conflicts, Art. 51(2), June 8, 1977, 1125 UNTS 3.

123 ICRC, Interpretive Guidance on the Notion of Direct Participation in HosTilities Under International Humanitarian Law 20 (2009).

${ }^{124} \mathrm{Id}$. at 27.

125 Yves Sandoz et al. (eds.), Commentary on the Additional Protocols of 8 June 1977 to the Geneva Conventions of 12 August $1949 \$ 2195$ (1987).

126 See, e.g., Chris Jenks et al., The Law of Armed Conflict: An Operational Approach 165 (2012).

127 AP II, supra note 3, Art. 13(3). 
force against a lawful target; there is no obligation to capture or minimize the use of force in IHL. ${ }^{128}$

Under IHRL, by contrast, the cardinal rule of targeting is that an individual must not be arbitrarily deprived of his right to life. ${ }^{129}$ Killing is not arbitrary as long as the use of lethal force is proportionate and necessary. ${ }^{130}$ The proportionality requirement limits the degree of force that a state may use in a particular situation. As summarized by Philip Alston, "the criterion of proportionality between the force used and the legitimate objective for which it is used requires that the escalation of force be broken off when the consequences for the suspect of applying a higher level of force would 'outweigh' the value of the objective."' 131 A state may use lethal force against a suspect, therefore, only when he poses a threat to the lives of others. ${ }^{132}$ The necessity requirement, in turn, "imposes an obligation to minimize the level of force applied regardless of the level of force that would be proportionate." 133 If a suspect who poses a threat to life can be apprehended or deterred through non-lethal means, using lethal force against him cannot be considered necessary. ${ }^{134}$ In practice, the necessity requirement means that the extraterritorial use of lethal force is justified only to prevent an imminent attack. Requiring imminence not only ensures that lethal force will be used only against suspects who genuinely intend to launch an attack, it also limits the use of lethal force to situations in which it is genuinely impossible to apprehend or deter the suspect. ${ }^{135}$

It is clearly more difficult to justify targeting under IHRL than under IHL $^{136}$ : IHRL rejects targeting based on status, strictly limits how much

128 Ian Henderson, The Contemporary Law of Targeting 79 (2009).

129 See, e.g., ICCPR, supra note 45, Art. 6. $\quad{ }^{130}$ Alston Report, supra note 83, 32.

131 Extrajudicial, Summary or Arbitrary Executions, Note by the Secretary-General, U.N. Doc. A/61/311 (September 5, 2006), 42.

${ }^{132}$ Id.; see also Basic Principles on the Use of Force and Firearms by Law Enforcement Officials, Adopted by the Eighth United Nations Congress on the Prevention of Crime and the Treatment of Offenders, Principle 9 (1990), available at www.unrol.org/doc .aspx? $\mathrm{d}=2246$.

133 Secretary-General's Note, supra note 131, 41.

134 See, e.g., Kretzmer, Targeted Killing, supra note 71, at 179; Michael Ramsden, Targeted Killings and International Human Rights Law: The Case of Anwar Al-Awlaki, $16 \mathrm{~J}$. Conflict \& Sec. L. 385, 400 (2011).

${ }_{135}$ Kretzmer, Targeted Killing, supra note 71, at 182.

136 See, e.g., Christian Tomuschat, Human Rights and International Humanitarian Law, 21 Eur. J. Int'L L. 15, 32 (2010); Marko Milanovic, A Norm Conflict Perspective on the Relationship between International Humanitarian Law and Human Rights Law, J. Confl. \& SeC. L. 459, 478 (2009); Expert Meeting on the Right to Life in Armed 
force can be used against a suspect, imposes a narrow time-frame on targeting, and requires capture when possible. Moreover, IHRL requires states to conduct "an independent and objective inquiry" whenever an individual is killed, while IHL requires an investigation only when there is reason to believe a war crime has been committed. ${ }^{137}$

Given these differences, it is not surprising that the U.S. has tried to expand the number of individuals who can be targeted in NIAC by analogizing to IAC. Although IHRL continues to apply during armed conflict, it is generally accepted that targeting is the one area in which IHL does, in fact, generally function as the lex specialis - either displacing competing rules of IHL or, as held by the ICJ in the Nuclear Weapons case, ${ }^{138}$ providing the test for when a killing in armed conflict should be considered "arbitrary." The wider the application of IHL in NIAC, therefore, the easier it is for the U.S. to justify using lethal force against members of "al-Qaeda and its associated forces."

\section{Membership in Organized Armed Groups}

As noted, IHL defines a "civilian" in NIAC negatively, as someone who is neither a member of the state's armed forces nor a member of an organized armed group. The distinction is critical, because non-civilians - normally referred to as combatants, even though that term does not appear in CA3 or AP II - may be attacked at any time, whereas civilians may only be targeted "for such time as" they directly participate in hostilities.

There is little controversy over who qualifies as a member of the State's armed forces in NIAC: "membership" is generally ${ }^{139}$ a formal criterion determined by domestic law. ${ }^{140}$ It is much less clear, however, who should be considered a member of an organized armed group, because AP II does not provide a definition of membership. The ICRC takes a functional approach to that question, according to which "the decisive

Conflicts and Situations of Occupation, University Centre for International Humanitarian Law, Geneva, at 8 (September 1-2, 2005), available at www.geneva-academy.ch/docs/ expert-meetings/2005/3rapport_droit_vie.pdf. Kretzmer, Rethinking, supra note 29, at 26; Doswald-Beck, supra note 49, at 887. Nuclear Weapons, supra note 48 , at 25.

139 AP II includes functional criteria as well. As the ICRC Commentary notes, AP II refers to "armed forces" instead of to "regular armed forces" because the drafters wanted to include armed forces "not included in the definition of the army in national legislation of some countries," such as "national guard, customs, police forces, or any other similar force." Commentary on the Additional Protocols, supra note 125, $\$ 4462$.

See Melzer, supra note 84, at 844-45. 
criterion for individual membership in an organized armed group is whether a person assumes a continuous function for the group involving his or her direct participation in hostilities." ${ }^{141}$ The ICRC thus excludes from membership - and thus from ongoing targetability - a variety of individuals "who continuously accompany or support an organized armed group, but whose function does not involve direct participation in hostilities," 142 most notably those who "assume exclusively political, administrative or other non-combat functions" in the group ${ }^{143}$ or assume "support functions" such as recruitment, training, financing, and propagandizing. ${ }^{144}$ According to the ICRC, the "continuous combat function" (CCF) definition of membership reflects customary international law. ${ }^{145}$

The U.S., by contrast, targets and detains on the basis of a much broader definition of membership in an organized armed group. Specifically, as Judge Walton acknowledged (with approval) in Gherebi, the USG takes the position that membership in an organized armed group should be determined by analogy to the definition of membership in a state's armed forces in IAC - thus relying on both formal and functional criteria:

As for the criteria used to determine membership in the "armed forces" of the enemy, the Court agrees with the government that the criteria set forth in Article 4 of the Third Geneva Convention and Article 43 of Additional Protocol I should inform the Court's assessment as to whether an individual qualifies as a member of the "armed forces" of an enemy organization like al-Qaeda. Although these provisions obviously cannot be applied literally to the enemy organizations contemplated in the AUMF - if that were the case, the conflict at hand would not be governed by Common Article 3 in the first place - they may nevertheless serve as templates from which the Court can glean certain characteristics necessary to identify those individuals who comprise an "armed force" for purposes of Common Article $3 .{ }^{146}$

141 DPH STUdy, supra note 123, at 33. $\quad{ }^{142}$ Id. at $34 . \quad{ }^{143} \mathrm{Id} . \quad{ }^{144} \mathrm{Id}$.

145 See Id. at 73 ("Under customary and treaty IHL ... persons assuming a continuous combat function for an organized armed group belonging to a party to the conflict, lose their entitlement to protection against direct attack.").

146 Gherebi v. Obama, 609 F. Supp. 2d 43, 68 (D.D.C. 2009); see also Respondents' Memorandum, supra note 9, at 5 (arguing that "standing U.S. jurisprudence, as well as law-of-war principles, recognize that members of enemy forces can be detained even if they have not actually committed or attempted to commit any act of depredation or entered the theatre or zone of active military operations."); Harold H. Koh, The Obama Administration and International Law, Speech to the American Society of International Law (March 25, 2010), available at www.state.gov/s/l/releases/remarks/139119.htm (arguing that membership "includes, but is not limited to, whether an individual joined with or became part of al-Qaeda or Taliban forces or associated forces, which can be demonstrated by relevant evidence of formal or functional membership"). 
This is a distinction with a difference, because the U.S. definition of membership brings within IHL's continuous targeting regime a category of individuals who could not lawfully be targeted under the ICRC definition: namely, anyone who qualifies as a member of an organized armed group under the U.S.'s dual formal/functional approach but does not assume a continuous combat function in the group. That is likely a sizable category, given the variety of "characteristics" the USG and courts believe qualify an individual as a member of organized armed group by analogy to GC III and AP I. Harold Koh, for example, publicly claimed while the State Department's Legal Adviser that taking an "oath of loyalty" to al-Qaeda qualifies as membership. ${ }^{147}$ Similarly, the DC Circuit has held that an individual can be considered a "facilitator" of al-Qaeda and thus "part of" the organization - if he stays at an al-Qaeda guesthouse, travels along a route that leads toward hostilities, and is captured with a large amount of unexplained cash. ${ }^{148}$ Needless to say, none of these actions even qualify as direct participation in hostilities.

It is important to note that, unlike the other analogies discussed in this chapter, the membership analogy does not use an IAC-based rule of IHL to fill a gap in the conventional and customary IHL of NIAC. There is a basis in conventional IHL for the concept of membership in an organized armed group; the question is simply how membership should be defined. Defining membership by analogy to state armed forces in IAC should thus probably be called "soft" analogy.

Nevertheless, the U.S. definition of membership in an organized armed group is still problematic. As discussed in Section I, analogized rules of IHL represent domestic humanitarian law, not international humanitarian law, and thus cannot be applied either territorially or extraterritorially in the face of contrary prohibitive rules of international law. Here there are such contrary prohibitive rules: namely, the rules of IHRL governing the use of lethal force. Those much more limiting IHRL rules can be displaced or modified by customary rules of IHL that apply in NIAC such as the rule that says a civilian can be targeted for such time as he or she directly participates in hostilities - but they cannot be displaced or

147

148 Almen

in v. Obama, 654 F.3d 1, 14-15 (D.C. Cir. 2011); cf. Uthman v. Obama, 637 F.3d 400, 405 (D.C. Cir. 2011) ("Being captured in the company of a Taliban fighter and two al Qaeda members and Osama bin Laden bodyguards 12 miles from Tora Bora in December 2001 might not be precisely the same as being captured in a German uniform 12 miles from the Normandy beaches in June 1944. But it is still, at a minimum, highly significant."). 
modified by an IAC-based rule that is applied to NIAC solely by analogy. As result, insofar as the U.S. definition of membership in an organized armed group goes beyond the customary definition of membership, the targeting of individuals who qualify as members under the former definition but not the latter is governed by IHRL, not by IHL. And there is little question that IHRL does not permit the use of lethal force at all much less the use of force at any time - against individuals who have sworn loyalty to al-Qaeda or who have "facilitated" terrorism by carrying cash and staying in al-Qaeda guesthouses.

Numerous scholars, primarily but not exclusively American, have criticized the ICRC's "continuous combat function" definition of membership. ${ }^{149}$ Interestingly, though, it is difficult to find a scholar who has challenged the ICRC's assertion that the definition reflects customary international law. ${ }^{150}$ Instead, criticism has focused almost exclusively on the fact that the CCF definition treats state armed forces and organized armed groups asymmetrically: because non-combat personnel in NIAC qualify as members of state armed forces but not as members of organized armed groups, state personnel can be targeted at any time, but non-state personnel can only be targeted while directly participating. ${ }^{151}$ Watkin's criticism of that asymmetry is typical:

The choice made in the Interpretive Guidance to treat organized armed groups in a completely different fashion than regular State armed forces in both international and non-international armed conflict is novel and problematic. It does not reflect either the nature of warfare or the historical and contemporary scope of armed conflict. In effectively creating a third category of participant in armed conflict, it represents a dramatic shift from the approach taken by the ICRC to date. ${ }^{152}$

149 See, e.g., Kenneth Watkin, Opportunity Lost: Organized Armed Groups and the ICRC "Direct Participation in the Hostilities" Interpretive Guidance, 42 N.Y.U. J. InT'L L. \& Pol. 641, 693-95 (2010); Bill Boothby, "And For Such Time As": The Time Dimension to Direct Participation in Hostilities, 42 N.Y.U. J. INT'L L. \& PoL. 741, 757 (2010); Michael N. Schmitt, The Interpretive Guidance on the Notion of Direct Participation in Hostilities: A Critical Analysis, 1 Harv. Nat. Sec. J. 5, 21-24 (2010); Sivakumaran, supra note 29, at $361-62$,

150 To the contrary, one scholar has noted that, despite the controversy, the continuous combat function definition "has substantial support among a wide cross section of states." See Jens Ohlin, The Assault on International Law 169-70 (2014). SivaKumaran, supra note 29 , at 361-62.

152 Watkin, Opportunity Lost, supra note 149, at 693; see also Boothby, supra note 149, at 757 (criticizing CCF for "creat[ing] legal inequality between the opposing parties, thus eroding the international law assumption that the law applies equally to each party to the conflict"); Schmitt, supra note 149, at 23 (criticizing the fact that, under the CCF test, "a 
This is an unpersuasive criticism. There is no question that conventional IHL is generally predicated on symmetry, even in NIAC: the rules of CA3 and AP II apply to both state armed forces and organized armed groups equally. ${ }^{153}$ From a positivist perspective, though, such symmetry is not an inherent requirement of IHL; no rule of international law prohibits states from adopting conventional or customary law that treats states and organized armed groups differently. ${ }^{154}$ Indeed, there is at least one asymmetry between states and organized armed groups in conventional IHL: the Protocol on the Involvement of Children in Armed Conflict (Children in Armed Conflict Protocol) ${ }^{155}$ ratified by 159 states, requires organized armed groups to avoid recruiting children under the age of eighteen, but permits States Parties to recruit children of any age as long as it is voluntary. ${ }^{156}$ As long as the ICRC is correct that conventional and customary IHL dictate the asymmetry between state armed forces and organized armed groups in terms of membership, therefore, it is difficult to see how that asymmetry could be legally problematic. ${ }^{157}$

Moreover, one of the primary critics of the membership asymmetry Watkin - has argued that members of the states armed forces are entitled to the combatant's privilege, but members of organized armed groups are not. ${ }^{158} \mathrm{He}$ does not explain why, as a matter of law, asymmetry in

cook in the regular armed forces may be lawfully attacked at any time; his or her counterpart in an organized armed group may be attacked only if he or she directly participates and then only for such time as the participation occurs").

153 Sassoli, Internment, supra note 54, at 602; Sivakumaran, supra note 29, at 303.

154 See Watts, supra note 56, at 150 (noting that "no 'equal application' principle operates in the present law of NIAC"); $c f$. Jonathan Somer, Jungle Justice: Passing Sentence on the Equality of Belligerents in Non-International Armed Conflict, 89 Int'L Rev. Red Cross 655,659 (2007) ("Yet while the principle [of equality] is undoubtedly established in the law of international armed conflict, there is good reason to question its status in the law of non-international armed conflict.").

$155 \mathrm{~A} / \mathrm{RES} / 54 / 263$ of 25 May $2000 . \quad{ }^{156} \mathrm{Id}$., $\$ \$ 3(3) \& 4(1)$.

157 It may, of course, be normatively problematic. See, e.g., Sivakumaran, supra note 29 , at 361-62.

${ }^{158}$ Kenneth Watkin, Warriors Without Rights? Combatants, Unprivileged Belligerents, and the Struggle over Legitimacy, Harvard Program on Humanitarian Policy and Conflict Research, at 65 (2005), available at www.hpcrresearch.org/sites/default/files/publica tions/OccasionalPaper2.pdf. But cf. Lawrence Hill-Cawthorne \& Dapo Akande, Does IHL Provide a Legal Basis for Detention in Non-International Armed Conflicts?, EJIL: TALK! (May 17, 2014), available at www.ejiltalk.org/does-ihl-provide-a-legal-basis-fordetention-in-non-international-armed-conflicts/ ("If IHL did indeed provide a legal basis for killing in a NIAC, it would have to do so on the basis of equality and would provide a privilege to kill (and a corresponding immunity from prosecution. It does not do this)."). 
membership is "novel and problematic," but asymmetry in the combatant's privilege is completely acceptable. Instead, he simply claims that extending the combatant's privilege to members of the state's armed forces but not organized armed groups is "logical."159

By contrast, another scholar who believes the combatant's privilege applies asymmetrically in NIAC, Ian Henderson, does try to provide a legal defense of that asymmetry. Henderson's argument is straightforward: state armed forces are entitled to the combatant's privilege because states have always insisted that "it is lawful for a government to engage in a non-international armed conflict with a non-state actor," while organized armed groups are not entitled to the privilege because states have equally insisted that "there is no legal right under international law for a non-state actor to engage in a non-international armed conflict." ${ }^{160}$ It is an open question whether Henderson's view of the combatant's privilege is correct; he and Watkin are in the (extreme) minority. ${ }^{161}$ But his underlying point is correct: if states want to asymmetrically apply the combatant's privilege to NIAC, whether as a matter of convention or custom, there is nothing stopping them from doing so. Henderson's position thus actually supports the idea that nothing in international law prohibits states from defining membership asymmetrically.

Finally, it is important to note that relying on the membership analogy makes it very likely the U.S. will engage in extraterritorial targeting that violates the jus ad bellum. The U.S., of course, takes a maximalist view of self-defense under Art. 51 - most famously declaring, in its 2002 National Security Strategy, that it is willing to act "even if uncertainty remains as to the time and place of the enemy's attack." ${ }^{\prime 62}$ This endorsement of preventive self-defense has been widely criticized, both by states ${ }^{163}$ and by scholars. ${ }^{164}$ But even accepting that there is still a great deal of uncertainty about the current state of self-defense under customary

159 Watkin, Warriors, supra note 158, at 65.

160 Ian Henderson, Civilian Intelligence Agencies and the Use of Armed Drones, 13 Y.B. INT'L Hum. L. 133, 150 (2010).

161 See, e.g., Kretzmer, Rethinking, supra note 29, at 35; Hill-Cawthorne \& Akande, supra note 158; Rona, supra note 40, at 114; Watts, supra note 56, at 149.

162 National Security Strategy of the United States 2002, at 15, available at www.state.gov/ documents/organization/63562.pdf.

163 See Kretzmer, Inherent, supra note 104, at 248 (noting that not even the United Kingdom, the U.S.'s closest ally, accepts the USG's view of self-defense).

164 See RuYs, supra note 93, at 322 (noting that "[o]n the whole, legal scholars have almost unisono denounced the doctrine of preventive self-defence"). 
international law, ${ }^{165}$ it is clear that the U.S.'s analogical expansion of membership in an organized armed group beyond the customary CCF standard is problematic, because it permits the U.S. to extraterritorially target a variety of individuals who cannot be legitimately attacked under any conception of self-defense. Assume, for example, that al-Qaeda has engaged in such a "chain of successive attacks" against the U.S. that the USG is entitled to use force not just to repel attacks as they happen, but also to prevent future attacks from taking place. ${ }^{166}$ In such a situation, it may well be possible to argue that the U.S. can legitimately use force against any member of al-Qaeda who assumes a continuous combat function in the group - the individuals who have taken part in the previous attacks and will take part in future ones. But it is difficult to see how self-defense could justify targeting "members" of the group who do not take part in combat - the cooks, the clerks, etc. Targeting them would appear to represent precisely the kind of "punitive" attack that is categorically impermissible under Art. 51. ${ }^{167}$ Such individuals, however, are lawful targets in NIAC if membership is defined by analogy to GC III and AP I. ${ }^{168}$

\section{Co-Belligerency}

According to the USG, the AUMF entitles it to use force not only against al-Qaeda, but also against its "associated forces." 169 To define the concept of an "associated force" of al-Qaeda, the USG has consistently analogized

165 See generally Christian J. Tams, The Use of Force Against Terrorists, 20 Eur. J. InT'L L. 359-97 (2009) (discussing the contested areas).

166 On the legal issues raised by this type of preventive self-defense, see Id. at 390; RuYs, supra note 84, at 116; Kretzmer, Inherent, supra note 104, at 271-72.

167 See Kretzmer, Inherent, supra note 104, at 254 (noting that using force "to punish for the harm done, either out of a feeling of justice or outrage," is "entirely foreign to selfdefence").

168 A skeptic might ask why, if this argument is correct, the jus ad bellum doesn't prohibit states from targeting cooks and clerks in an IAC. The answer is straightforward: in IAC, all members of a state's armed forces have the right to participate in hostilities. See GARY Solis, Law of ARmed Conflict 188 (2010). In other words, cooks and clerks can lawfully participate in armed attacks, even if they usually don't. They are thus included in the category of individuals self-defense can justify attacking under the jus ad bellum.

See, e.g., White Paper, supra note 85, at 1; Congressional Research Service, Al QaedaAffiliated Groups: Middle East and Africa, at 5 (October 10, 2014), available at http:// fpc.state.gov/documents/organization/233708.pdf (noting that "associated forces are considered legal targets of U.S. military force per the laws of armed conflict"); $c f$. National Defense Authorization Act for Fiscal Year 2012, Pub. L. No. 112-81, § 1021 (2011) (arguing same with regard to detention). 
to the concept of co-belligerency in IAC - the idea that a "fully fledged belligerent fighting in association with one or more belligerent powers" 170 is not entitled to invoke the protections of the law of neutrality. ${ }^{171}$ In a speech at the Oxford Union, Jeh Johnson, then General Counsel to the Department of Defense (DoD), stated that an "associated force" is "a co-belligerent with al Qaeda in hostilities against the United States or its coalition partners." ${ }^{\prime 12}$ In its notorious al-Aulaqi memo, the Department of Justice (DoJ) approved targeting "a leader of AQAP, an organized enemy force that is either a component of al-Qaida or that is a co-belligerent of that central party to the conflict." 173 And even more specifically, in the Hamlily litigation, the DoJ argued that the AUMF provides the USG "authority to detain individuals who, in analogous circumstances in a traditional international armed conflict between the armed forces of opposing governments, would be detainable under principles of co-belligerency." 174

Scholars have also argued that the concept of "associated forces" should be defined by analogy to co-belligerency. Bradley and Goldsmith have argued, for example, that because "[d]ictionary definitions" of "organization" are not useful, "[t]he international law concepts of neutrality and co-belligerency provide better guidance, and confirm that the 'enemy' in an armed conflict can include the enemy's affiliates":

These principles provide a guide for determining which terrorist organizations are included within the AUMF. Terrorist organizations that act as agents of al Qaeda, participate with al Qaeda in acts of war against the United States, systematically provide military resources to al Qaeda, or serve as fundamental communication links in the war against the United States, and perhaps those that systematically permit their buildings and safehouses to be used by al Qaeda in the war against the United States, are analogous to co-belligerents in a traditional war. Because the laws of war at a minimum would deem "neutrals" that systematically violate the laws of neutrality by supporting or assisting other terrorist organizations to be lawful military targets, the AUMF should be consistent with its text, with presidential practice in prior wars, and with standard delegation principles

170 Morris Greenspan, The Modern Law of Land Warfare 531 (1959).

171 Rebecca Ingber, Untangling Belligerency from Neutrality in the Conflict with Al-Qaeda, 47 Tex. INT'L L. J. 75, 90 (2011).

172 Jeh Johnson Speech, supra note 17. $\quad{ }^{173}$ White Paper, supra note 85, at 27.

174 Respondents' Memorandum, supra note 9, at 7. Although the brief specifically addressed detention, not targeting, the USG has never indicated that it believes co-belligerency is limited to the former power. 
extend to terrorist organizations that are functional co-belligerents of al Qaeda. ${ }^{175}$

The appeal of the co-belligerency analogy is evident: like the declarationof-war analogy, it ensures that targeting al-Qaeda's "associated forces" is governed by the rules of IHL instead of by the far more restrictive rules of IHRL. In the absence of co-belligerency, the U.S. could avoid IHRL only by demonstrating that it was involved in a separate NIAC with each and every associated force it wanted to target, either directly (in terms of hostilities between the U.S. and that associated force) or with the consent of a government involved in such a separate NIAC. ${ }^{176}$ For at least some terrorist groups outside of Afghanistan and Pakistan, such as al-Shabaab in Somalia and AQAP in Yemen, that could be difficult.

It is impossible to argue, though, that the concept of co-belligerency applies in NIAC. Co-belligerency is an aspect of the law of neutrality, as Bradley and Goldsmith openly acknowledge, and there is widespread scholarly agreement that the law of neutrality applies only in IAC. ${ }^{177}$ Indeed, the very idea that co-belligerency can be applied to NIAC by analogy is inconsistent with the law of neutrality; numerous scholars have pointed out that a state could traditionally invoke neutral rights and duties with regard to an insurgency only by recognizing the insurgents as belligerents, thereby - in modern terms - transforming the NIAC into an IAC. As Tucker says, "operation of the international law of neutrality presupposes, and is dependent upon, the recognition of insurgents in a civil war as belligerents. Prior to such recognition - whether by the parent state or by third states - there can be no condition of belligerency,

175 Bradley \& Goldsmith, supra note 22, at 2112-13; see also Robert Chesney, Thoughts on the Brennan Speech: Scope of the AUMF, CCF, JSOC, and Other Issues, LAWfare (May 2, 2012), available at www.lawfareblog.com/2012/05/thoughts-on-the-brennan-speechscope-of-the-aumf-ccf-jsoc-and-other-issues/ (arguing that the AUMF must reach the Haqqani Network, because they "are the NIAC equivalent to a classic 'co-belligerent' state"); Christopher Greenwood, International Law and the 'War Against Terrorism', 78 INT'L Afr. 301, 313 (2002) ("The Taliban - and thus Afghanistan - . . a the very least, its position was analogous to that of a neutral state which allows a belligerent to mount military operations from its territory.").

176 See Noam Lubell \& Nathan Derejko, A Global Battlefield? Drones and the Geographical Scope of Armed Conflict, 11 J. Int'l Crim. Just. 65, 83 (2013).

177 See, e.g., Robert W. Tucker, The Law of War and Neutrality at Sea 200 n. 8 (1955); Oppenheim, supra note 30, at 532; Quincy Wright, The Present Status of Neutrality, 34 Am. J. Int' L L, 391, 393 (1940); Stephen C. Neff, War and the LaW of Nations: A General History 260 (2005); Kress, supra note 50, at 266-67. 
hence no neutrality in the sense of international law." ${ }^{\prime 78}$ Finally, and perhaps most importantly, there is no evidence that any state other than the U.S. has ever invoked the law of neutrality - much less cobelligerency - in a NIAC. ${ }^{179}$

Because co-belligerency does not apply in NIAC as a matter of conventional or customary international law, the USG's adoption of that concept by analogy to IAC represents nothing more than "domestic humanitarian law." But that means the ostensible advantages of the analogy for the U.S. are illusory: in the absence of a separate NIAC with those groups, targeting members of al-Qaeda's "associated forces" remains subject to the prohibitive rules of IHRL, not IHL.

Indeed, the U.S.'s co-belligerency analogy is flawed in another respect. As discussed earlier, Goodman's argument that the U.S. is entitled to asymmetrically analogize between IAC and NIAC - applying the permissive IHL rules but not the prohibitive ones - depends on the idea, adopted by the PCIJ in the Lotus case, that "[r]estrictions upon the independence of States" concerning their domestic law "cannot ... be presumed." We have seen that, because of the rise of competing prohibitive rules of IHRL, the U.S.'s traditional freedom no longer exists in the realm of targeting and detention; unless the analogized IHL rule has a basis in customary international law, it cannot displace or modify a competing rule of IHRL. But even such a customary basis would not necessarily be enough to justify the co-belligerency analogy. As noted earlier, although symmetric rule application is not a necessary feature of IHL - states are always free to adopt asymmetrical rules via convention or custom - the "default" position is that IHL rules do, in fact, apply symmetrically in both IAC and NIAC. If that's the case, the U.S. could

178 TuCKer, supra note 177, at 200 n. 8; see also NefF, supra note 177, at 260 ("[T]his general legal bias in favor of governments against insurgents-in the absence of recognition of belligerency-was already widely accepted in state practice in the nineteenth century. If, on the other hand, the conflict was a civil war in the strict sense of the term, then the law of neutrality would apply."); Oppenheim, supra note 30 , at 532 ("[R] ecognition of belligerency alone brings about the operation of rules of neutrality as between the parties to the civil war and foreign States."); Wright, supra note 177, at 393 (noting, with regard to third states that assist the government to quell an insurgency, that "the word neutrality is hardly appropriate"); Note, International Law and Military Operations Against Insurgents in Neutral Territory, 68 Colum. L. Rev. 1127, 1128 n. 4 (1968) ("Strictly speaking, neutrality is a concept which applies only to international warfare, and its status in a civil war in which the rebels have not been recognized as belligerents is highly doubtful.").

See Kress, supra note 50, at 267. 
not justify using co-belligerency to target al-Qaeda's "associated forces" simply by showing that there is a customary basis for applying the law of neutrality in NIAC; it would also need to show that customary international law permits the law of neutrality to be applied asymmetrically in NIAC. The U.S. is not applying neutrality law in general to its NIAC with al-Qaeda. On the contrary: it is appropriating only those aspects of neutrality law that maximize its power to target and detain. And that is not a coincidence: for reasons I have discussed elsewhere, ${ }^{180}$ the U.S. would never apply the entire body of the law of neutrality to NIAC by analogy, because doing so would cripple its ability to fight al-Qaeda. Applied symmetrically, for example, the law of neutrality would entitle members of al-Qaeda to both the combatant's privilege and POW status upon capture. ${ }^{181}$ It would also prohibit the U.S. from establishing or maintaining military bases on the territory of any state that wanted to remain neutral in the U.S.'s NIAC with al-Qaeda. ${ }^{182}$

Finally, as with GC III/AP I membership, applying co-belligerency to NIAC by analogy is likely to lead to significant violations of the jus ad bellum - at least insofar as the U.S. follows Bradley and Goldsmith's approach, which at least one U.S. court has already done. ${ }^{183}$ As Bothe notes, in the post-Charter era, "[a]rmed reprisals are generally unlawful. As a consequence, a reaction against violations of neutrality which would involve the use of force against another state is permissible only where the violation of the law triggering that reaction itself constitutes an illegal armed attack." ${ }^{\prime 84}$ Bradley and Goldsmith, however, do not limit al-Qaeda's "associated forces" to organized armed groups that have attacked the U.S., either singly or alongside al-Qaeda; in their view, a group qualifies as an associated force as long as it "systematically violate[s] the laws of neutrality" by "provid[ing] military resources to al Qaeda or serv[ing] as fundamental communication links in the war against the United States." That is deeply problematic from a jus ad bellum standpoint, because

${ }^{180}$ Kevin Jon Heller, The Law of Neutrality Does Not Apply to the Conflict with Al-Qaeda, and It's a Good Thing, Too: A Response to Chang, 47 Tex. InT'L L. J. 115-41 (2011).

181 See Hersch Lauterpacht, supra note 34, at 175 ("Given the required conditions of belligerency as laid down by international law, the contesting parties are legally entitled to be treated as if they are engaged in a war waged by two sovereign States.").

182 See Oppenheim, supra note 30 , at 559 (noting that the duty of impartiality prohibits a neutral state from allowing a belligerent to "occupy a neutral fortress").

183 See Hamlily Memorandum Opinion, supra note 19, at 16.

184 Michael Bothe, The Law of Neutrality, in The Handbook of International Humanitarian Law 571, 581 (Dieter Fleck ed., 2nd ed. 2009). 
although such "unneutral service" by an organized armed group would entitle the U.S. to respond by imposing countermeasures, it would not entitle the U.S. to respond with military force:

A state not originally party to an armed conflict will only commit an act of war, and thus risk making itself a party to the conflict, by giving direct support to the military operations of one of the belligerents. Financial, political, and intelligence support will not have such an effect. ${ }^{185}$

The (invalid) co-belligerency analogy, in short, permits the U.S. to extraterritorially target individuals against whom it cannot lawfully use force in self-defense - namely, members of organized armed groups that become an "associated force" by providing al-Qaeda with non-military support. (The Nusra Front may be an example. ${ }^{186}$ ) After all, the point of the analogy is to allow the U.S. to target members of al-Qaeda's associated forces as if they were members of al-Qaeda itself.

\section{3. "Belonging to" and Associated Forces}

Ryan Goodman provides an alternative interpretation of "associated forces" but one that is no less based on analogy to IAC. In his view, an organized armed group qualifies as an "associated force" in the U.S./Al-Qaeda NIAC if it can be said to "belong to" al-Qaeda under Art. 4(a)(2) of GC III:

[T] he law of armed conflict stipulates that members of armed groups (e.g., AQAP) with a particular relationship to a party to a conflict (e.g., al-Qaeda) are legitimate targets. Specifically, Article 50(1) of Additional Protocol I states that a person cannot be considered a civilian (e.g., for the purpose of lethal targeting) if he is a member of an organized armed group with such an association. That association is defined in Article 4(a) (2) of the POW Convention: "members of other militias and members of other volunteer corps, including those of organized resistance movements, belonging to a Party to the conflict." In short, "belonging to" a

185

Christopher Greenwood, Scope of Application of Humanitarian Law, in Id. at 58; see also Michael Bothe, Neutrality in Naval Warfare: What Is Left of Traditional International Law, in Humanitarian LaW of Armed Conflict: Challenges Ahead 387, 396 (Astrid J.M. Delissen \& Gerard J. Tanja et al. eds., 1991) (“An unneutral service is not an armed attack, and it thus does not trigger a right of self-defence against the neutral State. Hence, the ius contra bellum excludes a reaction which would be legal under the traditional law of neutrality."); Wolf Heintschel von Heinegg, Visit, Search, Diversion and Capture in Naval Warfare, 30 Canadian Y.B. InT'L L. 89, 131 (1992) (“[U]nneutral service performed by a non-belligerent state would not be sufficient to justify the use of force against that state, since unneutral service is not an armed attack.").

See CRS Report, supra note 169 , at 43. 
party to the conflict is a form of an associated group, which renders its members subject to lethal force and detention. ${ }^{187}$

The "belonging to" analogy is just as problematic as the co-belligerency analogy - and for the same reasons. First, there is simply no evidence that Art. 4(a)(2) applies in NIAC. In terms of conventional law, neither CA3 nor AP II mention "belonging to," even though the former refers to "armed forces" and the latter (in Art. 1) refers to "organized armed groups." Moreover, Goodman cites no state practice - not even by the U.S., which takes a wider view of the material field of NIAC than any other state - in support of the idea that "belonging to" applies in NIAC as a matter of customary international law. ${ }^{188}$ The "belonging to" analogy thus represents the kind of domestic humanitarian law that is not capable of displacing or modifying the more restrictive targeting rules of IHL.

Second, although Art. 4(a)(2) of GC III permits members of resistance organizations who belong to a party to an IAC to be targeted, it also entitles them to the combatant's privilege and POW status upon capture. ${ }^{189}$ It would thus not be enough for Goodman to establish a customary basis for applying "belonging to" in NIAC. Because the default position in IHL is that rules apply to all parties equally, he would have to show that custom applies "belonging to" to NIAC asymmetrically permitting the U.S. to take advantage of its permissions without being bound by its prohibitions.

Third, and finally, apply the "belonging to" analogy to the U.S./ al-Qaeda NIAC would create even more serious jus ad bellum problems than co-belligerency. As Goodman notes, "belonging to" is an easily satisfied standard in IAC; according to the ICRC Commentary to GC III, the necessary "de facto" relationship between the resistance organization and the party to the conflict "may find expression merely by tacit agreement, if the operations are such as to indicate clearly for which side the resistance organization is fighting." ${ }^{\prime 90}$ Needless to say, if the U.S. would violate the jus ad bellum by targeting organized armed groups that

Ryan Goodman, Al-Qaeda, the Law on Associated Forces and "Belonging To" a Party, Just SeCURITy (October 18, 2003), available at http://justsecurity.org/2191/al-qaedalaw-forces-belonging-to-party-drones-reports/.

188 Notably, the ICRC study of custom does not indicate that "belonging to" applies in NIAC. See Customary IHL Study, supra note 4, at Rule 4.

189 Assuming, of course, they satisfy the four criteria mentioned in the provision.

190 ICRC, Commentary on the Geneva Convention (III) Relative to the Treatment of Prisoners of War 57 (Jean S. Pictet ed., 1960). 
become an "associated force" by providing al-Qaeda with non-military support, it would violate the jus ad bellum by targeting organized armed groups that become an "associated force" simply by tacitly agreeing to support al-Qaeda. ${ }^{191}$

\section{Detention}

In IAC, conventional IHL both authorizes and regulates detention. Art. 21 of GC III provides that a state "may subject prisoners of war" generally members of the enemy's armed forces - "to internment." Because POWs are presumed to pose a security threat simply by virtue of their right to participate in hostilities, ${ }^{192}$ they can be detained without any kind of review until "the cessation of active hostilities." ${ }^{193}$ The detention of civilians, in turn, is governed by the Fourth Geneva Convention (GC IV). Art. 42(1) permits a state to detain a civilian on its own territory if its security "makes it absolutely necessary," while Art. 78(1) permits a state to detain a civilian in occupied territory if it "considers it necessary, for imperative reasons of security" - although it is generally agreed that there is little, if any, substantive difference between the two standards. ${ }^{194}$ Civilian detention must end "as soon as the reasons which necessitated his internment no longer exist"195 and cannot extend beyond the "cessation of hostilities." ${ }^{196}$ GC IV thus requires the detaining state to continually review whether detention is warranted. For civilians detained on state territory, the initial decision to detain must be "reconsidered as soon as possible by an appropriate court or administrative board designated by the Detaining Power for that purpose" and must be reviewed by the same court or administrative board at least twice per year thereafter. ${ }^{197}$ Civilians detained in occupied territory have the right to

191 To be sure, insofar as a "tacit agreement" led an organized armed group to launch its own armed attack against the U.S., the U.S. could lawfully target members of the group. In such situations, however, the group's targetability under the jus ad bellum would in no way depend on its status as an "associated force."

192 See ICRC Position Paper, Internment in Armed Conflict: Basic Rules and Challenges, at 4 (Nov. 2014), available at www.icrc.org/en/document/internment-armed-conflictbasic-rules-and-challenges\#.VKvETIqsUmc.

193 GC III, supra note 10, Art. 118(1).

194 See ICRC, Commentary on the Geneva Convention (IV) Relative to the Protection of Civilian Persons in Time of War 367 (Jean S. Pictet ed., 1958).

195 Convention Relative to the Treatment of Prisoners of War, August 12, 1949, Art. 132(1), 6 U.S.T. 3316, 75 U.N.T.S. 135, 136.

196 Id., art. 133(1). ${ }^{197}$ Id., art. 43(1). 
appeal their detention and, if their detention is upheld, the right to "periodical review, if possible every six months, by a competent body set up by the said Power." 198

In NIAC, by contrast, conventional IHL is largely silent concerning detention. Unlike GC III and GC IV, neither CA3 nor AP II contain a provision that authorizes a party to a NIAC to detain anyone - member of the state's armed forces, member of an organized armed group, or civilian. ${ }^{199}$ The authorization for detention is left to domestic law. ${ }^{200}$ Moreover, neither CA3 nor AP II specifies any "procedural safeguards for persons interned in NIAC," even though they each recognize that such detention will take place. ${ }^{201}$ Instead, their purpose "is simply to guarantee a minimum level of humanitarian treatment for people who are in fact detained."202

Because IHL authorizes and regulates detention in IAC but not in NIAC, the relationship between IHL and IHRL is very different in the two kinds of armed conflict. In IAC, the rules of IHL predominate; as the ICRC notes, "[a]s the lex specialis crafted specifically for situations of armed conflict, IHL applicable in IAC is the interpretive tool by means of which the interplay between this body of norms and HR law may be determined. ${ }^{203}$ By contrast, the absence of detention-related rules of IHL in NIAC means that IHRL predominates under either possible version of the lex specialis principle - as partial displacement or as norm-conflict resolution. If there is no IHL lex, IHL cannot be lex specialis. ${ }^{204}$

198 Id., art. 78(2).

199 See, e.g., Expert Meeting on the Supervision of the Lawfulness of Detention During Armed Conflict, University Centre for International Humanitarian Law, Geneva, at 3 (July 24-25, 2004), available at www.geneva-academy.ch/docs/expert-meetings/2004/ 4rapport_detention.pdf; Rona, supra note 40, at 114; Hill-Cawthorne \& Akande, supra note 158; Serdar Mohammed v. Ministry of Defence [2014] EWHC 1369 (QB), g 251.

200 See, e.g., Expert Meeting on Supervision of Detention, supra note 199, at 3; HillCawthorne \& Akande, supra note 158.

201 ICRC Position Paper, supra note 192, at 6; see also Sassoli, Internment, supra note 54, at 623; Hill-Cawthorne \& Akande, supra note 158.

202 Mohammed, supra note 199, g 251.

203 ICRC Position Paper, supra note 192, at 3; Kress, supra note 50, at 262.

204 See, e.g., Sassoli, Internment, supra note 54, at 621 ("As humanitarian law applicable to non-international armed conflict is silent on the procedural regulation of internment, it would seem clear that in accordance with the lex specialis principle as a maxim of logic, human rights should step in to fill the gap."); Expert Meeting on Supervision of Detention, supra note 199, at 3 (noting that because "the grounds and procedure of detention" are not regulated by IHL in NIAC, "only national law is relevant, as well as international human rights law"); Rona, supra note 40, at 114 ("NIAC fighters are mere 
IHRL significantly limits the ability of states to detain in NIAC. IHRL does not categorically prohibit detention; a state is entitled to detain individuals who commit a criminal offense or pose a legitimate threat to its security. ${ }^{205}$ But there is little question that IHRL imposes much greater procedural restrictions on detention than conventional IHL in IAC, as the Human Rights Committee made clear in its recent General Comment No. 35 (Liberty and Security of the Person):

To the extent that States parties impose security detention (sometimes known as administrative detention or internment), not in contemplation of prosecution on a criminal charge, the Committee considers that such detention presents severe risks of arbitrary deprivation of liberty. Such detention would normally amount to arbitrary detention as other effective measures addressing the threat, including the criminal justice system, would be available. If under the most exceptional circumstances, a present, direct and imperative threat is invoked to justify detention of persons considered to present such a threat, the burden of proof lies on States parties to show that the individual poses such a threat and that it cannot be addressed by alternative measures, and this burden increases with the length of the detention. States parties also need to show that detention does not last longer than absolutely necessary, that the overall length of possible detention is limited, and that they fully respect the guarantees provided for by Article 9 in all cases. Prompt and regular review by a court or other tribunal possessing the same attributes of independence and impartiality as the judiciary is a necessary guarantee for these conditions, as is access to independent legal advice, preferably selected by the detainee, and disclosure to the detainee of, at least, the essence of the evidence on which the decision is taken. ${ }^{206}$

Three procedural differences between IHRL and IHL in IAC are particularly critical. First, and most obviously, IHRL security detention does not distinguish between POWs and civilians; the same protections apply to both. It is thus not possible under IHRL to detain anyone without periodic review. ${ }^{207}$ Second, IHRL entitles all detained individuals to periodic review of their detention by a court or quasi-judicial

criminals under domestic law, and so, rules concerning their detention fall under domestic law, tempered by international human rights obligations.").

Id., 15; see also Lawrence Hill-Cawthorne, The Copenhagen Principles on the Handling of Detainees: Implications for the Procedural Regulation of Internment, 18 J. ConfLICT \& SEC. L. 481, 485 (2013). Under the ECHR, security detention likely requires derogation. But that requirement is not germane to this discussion.

206 HRC General Comment 35, supra note 65, 15.

${ }^{207} \mathrm{Id}$. The right to review is also non-derogable. $I d$., 67. 
tribunal, whereas IHL only requires periodic review by a court or "administrative body." Although the difference between IHRL's "other tribunal" and IHL's "administrative body" is not completely clear, most scholars agree that the former must be more independent than the latter. ${ }^{208}$ Third, and finally, IHRL makes it difficult, if not impossible, to justify detaining someone until the end of an armed conflict ${ }^{209}-$ particularly in a transnational NIAC involving terrorist groups, where "[n]ot only can we not envision an end to the hostilities, but more problematic, we have absolutely no way of identifying what that end might look like." 210

These differences almost certainly explain why the U.S. has consistently relied on analogy to apply IAC-based IHL detention rules in NIAC. $^{211}$ They also explain why certain scholars have relied on analogy to argue that organized armed groups have the right to detain. None of those analogies, however, withstand critical scrutiny.

\section{General Detention Power}

The first two analogies, which can be addressed together, are unsurprising: analogizing to IAC to define the general detention power in NIAC with regard to organized armed groups and civilians. The U.S. considers members of organized armed groups to be "unprivileged belligerents" who "may lawfully be detained until a competent authority determines that the conflict has ended or that active hostilities have ceased"212 language that precisely mirrors Art. 118(1) of GC III. Similarly, the U.S. takes the position that civilians may be interned "for imperative reasons of security" and must be "released when the reasons that necessitated

208 See, e.g., Hill-Cawthorne, supra note 205, at 208.

209 See, e.g., Fiona de Londras, Detention in the 'War on Terror': Can Human Rights Fight BACK? 192 (2011).

${ }^{210}$ Laurie R. Blank, A Square Peg in a Round Hole: Stretching Law of War Detention Too Far, 63 Rutgers L. Rev. 1169, 1181 (2011).

211 Cf. Marco Sassoli, Transnational Armed Groups and International Humanitarian Law, Harvard Program on Humanitarian Policy and Conflict Research, at 27 (2005), available at www.hpcrresearch.org/sites/default/files/publications/OccasionalPaper6.pdf (noting that "[o]ne of the reasons why the United States administration so obstinately wants to apply the laws of war to its struggle against international terrorism is, arguably, that it considers it necessary in that struggle to have recourse to war-like internment which goes beyond what the human rights supervisory bodies admit outside declared situations of emergency").

212 DoD Directive, supra note 11, 3(f). 
internment no longer exist and a safe and orderly transfer or release is practicable"213 - the GC IV standard for interning civilians in occupied territory. Both categories are entitled to period review of their detention by a "competent authority" ${ }^{14}$ - another GC IV reference - which must be a military judge for "unprivileged belligerents held in long-term detention."

Scholars also support the analogies to GC III and GC IV. In Goodman's view, for example, because "the Fourth Geneva Convention does generally contain the most closely analogous rules concerning the detention of civilians," it "constitutes the best approximation of IHL rules when interpretive gaps arise." ${ }^{16}$ Similarly, Kress suggests that "[i]n line with the most recent practice of the USA, in particular," states are increasingly likely to adopt an "an 'armed conflict model' for preventive detention" in NIAC "through 'translation' or analogizing principles from the laws of war governing traditional" IACs. ${ }^{217}$

There is, however, an important methodological difference between Goodman and Kress: while Goodman claims that nothing prevents the U.S. from applying GC IV's detention standards in NIAC, Kress argues - or at least strongly implies - that those standards could only be applied in NIAC if a sufficient number of states adopted the U.S.'s analogy to GC IV. In other words, while Goodman believes that the U.S. analogy is already lex lata, Kress believes that it is currently lex ferenda that could become lex lata as a matter of customary international law.

Kress is absolutely right. Nothing in international law would prohibit states from applying GC IV's detention regime to NIAC through convention or custom. Indeed, through convention or custom, states could apply GC III's much more detention-friendly regime to members of organized armed groups, civilians who DPH, and even ordinary civilians. As discussed earlier, no matter how we understand the lex specialis principle, a clear and specific conventional or customary rule of IHL will have priority in an armed conflict - IAC or NIAC - over a competing conventional or customary rule of IHRL.

\footnotetext{
213 Id., g 3(m)(5). $\quad{ }^{214}$ Id., g 3(m)(1). $\quad{ }^{215}$ Id., g 3(i).

216 Goodman, Detention of Civilians, supra note 24, at 50. Interestingly, Goodman does not explain why the U.S. could not maximize its detention authority by analogizing to GC III instead of to GC IV. He simply says that GC IV "constitutes the best approximation of IHL rules when interpretive gaps arise." If analogy is a legitimate source of IHL, however, an analogy's ostensible substantive fit would seem to be irrelevant.

217 Kress, supra note 50, at 264.
} 
The problem with the U.S. position is that, as Kress implies, the available state practice is insufficient to conclude that customary IHL authorizes detention in NIAC ${ }^{218}$ - much less that it authorizes detention by reference to GC III and/or GC IV. The U.S. analogies to IAC thus fail for the same reason they fail in the context of targeting: an analogized rule represents domestic humanitarian law, which is not capable of displacing or even modifying IHRL. ${ }^{219}$ Detention in NIAC is simply not an area of international law in which "every State remains free to adopt the principles which it regards as best and most suitable." On the contrary, there are now prohibitive rules of IHRL that, via lex specialis, define the limits of NIAC detention. And as we have seen, those prohibitive rules simply do not permit detention on par with GC III or GC IV - particularly the kind of indefinite detention that GC III contemplates.

It is also worth highlighting another problem with the U.S.'s analogy to GC III: its asymmetry. Although Art. 4 of GC III permits a state to detain combatants until the end of hostilities, such detainees are entitled to POW status. ${ }^{220}$ As we saw in the context of targeting, therefore, it would not be enough for the U.S. to establish a customary rule extending GC III's detention power to NIAC. Because the default position is that IHL applies symmetrically, it would have to show that custom permits it to apply the permissive rules of IHL (detention) while ignoring its prohibitive rules (POW status).

218 See, e.g., Mohammed, supra note 199, 257 ("I have been shown no evidence of any recognition by states involved in noninternational armed conflicts of IHL as providing a legal basis for detention.... Nor has the MOD pointed to any official statement by the UK government (or any other government) which suggests that IHL does, or could, provide a legal basis for detention in any non-international armed conflict."); Hill-Cawthorne \& Akande, supra note 158 ("That the legal basis for detention in NIACs does not lie in IHL, whether as an implied right or a customary right, is supported by state practice.... If either the applicable treaty provisions or customary international law could be said to provide a legal basis for detention in NIACs, one would expect practice generally to confirm this. This does not, however, seem to be the case.").

219 See Hill-Cawthorne \& Akande, Locating the Legal Basis for Detention in Non-International Armed Conflicts: A Rejoinder to Aurel Sari, EJIL: TALk! (June 2, 2014), available at www.ejiltalk.org/locating-the-legal-basis-for-detention-in-non-international-armed-con flicts-a-rejoinder-to-aurel-sari/ ("That IHL should provide such a basis [for detention in NIAC] as a matter of logic (with which one may or may not agree) cannot make up for this lack of supporting practice.").

220 See GC III, supra note 10, Art. 4(A) (defining POWs as "persons belonging to one of the following categories, who have fallen into the power of the enemy"). 


\section{Substantial Support}

The U.S. does not believe that it is limited to detaining individuals who are members of al-Qaeda or one of its associated forces. It also takes the position that it can detain anyone who "substantially supports" any such group. The USG thus defines "unprivileged belligerents" - who may be detained until "the conflict has ended or ... active hostilities have ceased" - as "[i]ndividuals who have forfeited the protections of civilian status by joining or substantially supporting an enemy non-state armed group in the conduct of hostilities." ${ }^{211}$ That position, as the USG openly acknowledges, is based on analogy to IAC - in particular, to the "persons accompanying" provision of GC III:

The term "substantial support" covers support that, in analogous circumstances in a traditional international armed conflict, is sufficient to justify detention. The term thus encompasses individuals who, even if not considered part of the irregular enemy forces at issue in the current conflict, bear sufficiently close ties to those forces and provide them support that warrants their detention in prosecution of the conflict. See, e.g., Geneva Convention III, Art. 4.A(4). ${ }^{222}$

Courts have consistently upheld the U.S.'s right to detain individuals who substantially support al-Qaeda or its associated forces, ${ }^{223}$ and at least one has implicitly adopted the analogy to GC III's "persons accompanying" provision. In al-Bihani, the appellant argued that he could not be lawfully detained because he was nothing more than a "civilian 'contractor' rendering services" to one of al-Qaeda's associated forces. ${ }^{224}$ The DC Circuit rejected that argument - but held that he would be detainable even if he was not a member of that associated force, because substantial support "clearly include[s] traditional food operations essential to a fighting force and the carrying of arms."225

Applying the "persons accompanying" provision in Art. 4(A)(4) of GC III to NIAC by analogy, however, is no less problematic than applying by

DoD Directive, supra note 11 , at 14 ; see also 2012 NDAA, supra note $171, \S 1021$ (providing that the AUMF's detention power extends to individuals who provide substantial support).

222 Quoted in Ryan Vogel, The DoD Detainee Directive and Its Definition of "Unprivileged Belligerency, "Just Security (September 22, 2014), available at http://justsecurity.org/ 15312/dod-detainee-directive-definition-unprivileged-belligerency/; see also Lederman \& Vladeck, supra note 23 (“[P] apprehended while accompanying such forces can be detained on roughly the same terms as the forces themselves, just as they can be in an international conflict.").

See, e.g., Al-Bihani, supra note 20, at $872 .{ }^{224}$ Id. at $873 .{ }^{225}$ Id. 
analogy Art. 21 of GC III and Arts. 42(1) and 78(1) of GC IV. Conventional IHL limits the detention of "persons accompanying" to IAC, and there is no evidence that the rule applies in NIAC as a matter of customary international law. Indeed, as Danner notes, the idea that individuals who support organized armed groups are detainable in the same way as members of organized armed groups comes not from IHL, but from "the domestic law of complicity, which targets those who aid and abet the principal perpetrators of crimes." 226 The "persons accompanying" analogy is thus precisely the kind of domestic humanitarian law that cannot supplant a competing prohibitive rule of IHRL.

To be sure, IHRL does not necessarily prohibit the U.S. from detaining individuals who substantially support al-Qaeda or one of its associated forces. IHRL's priority simply means that the U.S. must determine the detainability of a substantial supporter by reference to IHRL - the "present, direct and imperative threat" standard, in particular - and must afford anyone thereby detained all of IHRL's procedural guarantees. Many actions the USG considers "substantial support" likely satisfy the IHRL standard, such as financing or recruiting for al-Qaeda. Cooking for an associated force of al-Qaeda, however, clearly does not.

\section{Detention by Organized Armed Groups}

All of the analogized rules of IHL discussed thus far reflect the U.S.'s desire to maximize its targeting and detention power in NIAC. A few scholars, by contrast, have relied on analogy expand the power of organized armed groups - in particular, by contending that GC III entitles such groups to detain members of the state's armed forces. Casalin argues, for example, that because CA3 and AP II do not prohibit detention by organized armed groups and even seem to contemplate it, the circumstances in which such detention is acceptable should be defined "using the analogous IHL of international armed conflict (i.e., the standards of Geneva Convention III)":

Detention by armed opposition groups in a situation analogous to those prescribed by the law of international armed conflict would therefore not be considered arbitrary for want of a legal basis, since Common Article 3 (and, in certain cases, Article 5 of Additional Protocol II) serves

226 Allison M. Danner, Defining Unlawful Enemy Combatants: A Centripetal Story, 43 Tex. INT'L L. J. 1, 12 (2007). 
as the preexisting legal grounds for detention.... In such a case, Geneva Convention III would then be used for guidance in interpretation of what it means to detain in connection with hostilities. This could be considered a type of "quasi-POW" detention (i.e., imprisonment of enemy fighters for the purpose of placing them hors de combat). ${ }^{227}$

The problem with this analogy is a familiar one: a permissive rule applied to NIAC from solely by analogy to IAC cannot supplant a competing prohibitive rule of IHRL under any conception of lex specialis. Here such an IHRL rule clearly exists: namely, that detention in NIAC is permissible only insofar as it is authorized by law. ${ }^{228}$ Only such authorization ensures that detention in NIAC is neither arbitrary nor unlawful. ${ }^{229}$ In IAC, IHL itself provides the necessary authority to detain; domestic authorization is not necessary. ${ }^{230}$ IHL does not, however, authorize detention in NIAC; the necessary authorization is left to domestic law. Any attempt to rely on analogy to argue that organized armed groups can detain members of the state's armed forces is thus doomed to fail. As Casalin herself notes, "the domestic law of all states prohibits detention by armed opposition groups." ${ }^{231}$ IHRL thus does not permit organized armed groups to detain anyone. ${ }^{232}$

227 Casalin, supra note 54, at 754; see also Sassoli, Internment, supra note 54, at 623 ("Applied by analogy, the humanitarian law of international armed conflict allows for internment and provides for review procedures ... Given the organizational criteria a non-state actor must meet to be considered a party to an armed conflict, any non-state actor should be able to fulfill these obligations.").

228 See, e.g., HRC General Comment 35, supra note 65, 44; Hill-Cawthorne, supra note 205 , at 485 .

229 See HRC General Comment 35, supra note 65, 11.

${ }^{230}$ ICRC Position Paper, supra note 192, at 4 (noting that this position is "generally uncontroversial").

231 Casalin, supra note 54, at 744; see also Liesbeth Zegveld, Accountability of Armed Opposition Groups in International LaW 66 (2002) ("Human rights treaties presume the state to be the only authority within the state territory, and under this law the state, represented by a government, is the only authority entitled to arrest and detain persons on such grounds and in accordance with the law.").

${ }^{232}$ It is worth noting that Casalin's reliance on analogy is oddly selective. Although she believes that IHL permits organized armed groups to detain members of the state's armed forces in NIAC, she insists that the detention of civilians continues to be determined by IHRL. Casalin, supra note 54, at 755 . She also argues that analogy to IAC provides only the authorization to detain members of the state's armed forces; the procedural limits on their detention must still be determined by IHRL. Id. Casalin never explains why, if analogy is permissible, organized armed groups must appropriate only those aspects of IHL that she finds normatively desirable. 


\section{Conclusion}

Karl Rove once famously accused Democrats who opposed the Bush Administration's counterterrorism policies of having a "pre-9/11 mindset." 233 As it turns out, the USG as a whole has a "pre-1949" mindset its consistent reliance on analogy to maximize its ability to target and detain harkens back to an age before World War II, when noninternational conflicts were actually non-international and universal human rights were nothing more than a gleam in Eleanor Roosevelt's eyes. In that Lotus-dominated era, no prohibitive rules of international law prevented a state from adopting whatever targeting and detention rules it considered "best and most suitable" for quelling an insurgency; if it wanted to look to international armed conflict for inspiration, it was free to do so.

The legal landscape, however, has changed dramatically since World War II. In a NIAC, IHL is no longer the only game in town; both targeting and detention are also subject - at least potentially - to IHRL's prohibitive rules. And NIAC is no longer predominantly noninternational; transnational NIACs are now the norm, not the exception. Prohibitive rules that protect a state's sovereignty - the principle of nonintervention and the prohibition on the use of force - thus also affect how a state fights a NIAC.

In our legally overdetermined era of transnational armed conflict, there is simply no room in IHL for analogy between IAC and NIAC. First and foremost, there is the IHRL problem. IHRL prevents analogy because analogized rules have no basis in either conventional or customary IHL; they are simply rules of domestic humanitarian law that cannot supplant contrary rules of IHRL under any conception of lex specialis. And then there is the sovereignty problem. Analogized rules may not necessarily violate the principle of non-intervention and the prohibition on the use of force; it is always possible to imagine situations in which self-defense would permit the U.S. to extraterritorially target or detain individuals who have become targetable or detainable because of a rule analogized from IAC to NIAC. But there are far more scenarios in which analogized rules will permit - even encourage - the U.S. to use force extraterritorially in a manner that is inconsistent with the principle of non-intervention and the prohibition on the use of force. Analogy thus makes it exceptionally likely, if not actually certain, that the U.S. will routinely use extraterritorial force unlawfully.

233 Branden Crocker, Over the Top, American Spectator (February 15, 2006). 
The Permanent Court of International Justice held in 1927 that "[r]estrictions upon the independence of States cannot ... be presumed." That principle was sound in the era in which it was written. But that is not our era. In the Age of Rights, the U.N. Charter, and transnational armed conflict, such restrictions no longer have to be presumed - they exist throughout positive international law. 
